OPEN ACCESS

Edited by:

Yngvar Olsen

Norwegian University of Science and Technology, Norway

Reviewed by:

Kang-le Lu, Jimei University, China

Chunxiao Zhang,

Jimei University, China

*Correspondence: Qihui Yang

qihuiyang03@163.com

tORCID:

Qihui Yang

orcid.org/0000-0001-9107-2541

Huaxing Lin

orcid.org/0000-0003-2333-6327

Specialty section: This article was submitted to Marine Fisheries, Aquaculture and Living Resources,

a section of the journal

Frontiers in Marine Science

Received: 15 November 2021 Accepted: 30 December 2021 Published: 23 February 2022

Citation:

Lin H, Tan B, Ray GW, Zeng M, Li M, Chi S and Yang Q (2022) A Challenge to Conventional Fish Meal: Effects of Soy Protein Peptides on Growth, Histomorphology, Lipid Metabolism and Intestinal Health for Juvenile Pompano Trachinotus ovatus. Front. Mar. Sci. 8:815323. doi: 10.3389/fmars.2021.815323

\section{A Challenge to Conventional Fish Meal: Effects of Soy Protein Peptides on Growth, Histomorphology, Lipid Metabolism and Intestinal Health for Juvenile Pompano Trachinotus ovatus}

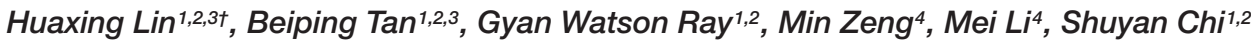 \\ and Qihui Yang ${ }^{1,2,3 *+}$
}

\footnotetext{
${ }^{1}$ College of Fisheries, Guangdong Ocean University, Zhanjiang, China, ${ }^{2}$ Aquatic Animals Precision Nutrition and High Efficiency Feed Engineering Research Center of Guangdong Province, Zhanjiang, China, ${ }^{3}$ Guangdong Provincial Key Laboratory of Pathogenic Biology and Epidemiology for Aquatic Economic Animals, Zhanjiang, China, ${ }^{4}$ Yisheng (Yangjiang) Biotechnology Company Limited, Yangjiang, China
}

This experiment was conducted to assess the possibility of replacing fish meal (FM) with soy protein peptide (SPP) at different levels-0\% (FM), 14.29\% (S5), 28.57\% (S10), $57.14 \%$ (S20), $71.42 \%(\mathrm{~S} 25)$ - and its effects on growth, histology, gene expression related to liver lipid metabolism and intestinal immunity in juvenile pompano Trachinotus ovatus (initial mean weight $=39.88 \pm 0.15 \mathrm{~g}$ ). 600 healthy and uniformed-size fish were distributed to five groups of three replicates, each with 40 fish in each floating cage and fed twice daily for 8 weeks. Results showed that no significant difference in the growth was observed with SPP replacing FM $(P>0.05)$. Serum glutathione peroxidase activity in the S10 group was significantly higher than that in the FM group, and serum malondialdehyde content significantly decreased $(P<0.05)$. SPP significantly improved intestinal immunity by increasing alkaline phosphatase and lysozyme activities and up-regulating interleukin 10 and complement 4 mRNA levels while simultaneously decreasing triglyceride and total cholesterol content and down-regulating interleukin $1 \beta$ mRNA expression. Villus length and muscle thickness in the $\mathrm{S} 10$ group were significantly higher than those in the FM group $(P<0.05)$. SPP significantly improved liver fat metabolism by increasing carnitine palmitoyl transferase I mRNA levels, and down-regulating fatty acid synthesis mRNA expression $(P<0.05)$. In summary, SPP substitution for FM promoted intestinal health, liver lipid metabolism and reduced liver fat accumulation for juvenile pompano T. ovatus, with no significant effect on growth performance. Based on the second-order polynomial analysis model of LYZ activity, the optimal replacement SPP level for juvenile pompano T. ovatus was $11.82 \%$.

\footnotetext{
Keywords: Trachinotus ovatus, soy protein peptide, fish meal, histological morphology, lipid metabolism
} 


\section{HIGHLIGHTS}

- The replacement of FM with partial SPP can significantly improve disease resistance without affecting growth performance for juvenile pompano Trachinotusovatusunder experimental conditions.

- By analyzing serum immune indexes, intestinal histology and intestinal immune-related genes, the replacement of $10 \% \mathrm{FM}$ with SPP significantly promotes the intestinal healthforjuvenile pompano Trachinotusovatus.

- Based on the broken-line regression analysis model of LYZ activity in serum, the SPP optimal replacement level for juvenile pompano Trachinotusovatus is $12.80 \%$.

\section{INTRODUCTION}

Fish meal (FM) has high amounts of proteins, essential amino acids, N-3 polyunsaturated fatty acids, and vitamins and has been the most used protein source in the compound feed of pompano Trachinotus ovatus (Zhang et al., 2018). However, the declining world fish meal production and the rising prices lead to an increasingly prominent conflict between supply and demand (Tacon and Metian, 2008). The increasing cost of feed has severely limited the sustainable development of the aquafeed industry. Therefore, nutrient-rich, efficient, and environmentally friendly plant protein sources as replacements for FM has become a major topic in the aquatic feed industry (Food and Agriculture Organization [FAO], 2014).

Alternative protein sources are essential to the growth of the aquaculture industry (Tacon, 2003) and can be used to reduce protein sources from FM (Naylor et al., 2000). The final products of protein digestion in the digestive tract mainly originate from small peptides rather than from free amino acids, and enter the blood circulation in the form of two or three peptides (Liu et al., 2007; Zhou et al., 2011). Peptides as feeding materials have been widely studied. Peptides can strengthen the immune system, reduce feed coefficient rate, and accelerate protein synthesis (Liang et al., 2020a; Wang J.X. et al., 2020). In Gadus morhua (Aksnes et al., 2006a), Salmo salar (BØGwald et al., 1996), Dicentrarchus labrax (Kotzamanis et al., 2007), and Litopenaeus vannamei (Gyan et al., 2020), similar improvements in weight gain rate, feed efficiency, and survival were observed (Savoie et al., 2006). In addition, small peptides preferentially act as energy substrates for the intestinal mucosa and can effectively promote the development of intestinal mucosal tissue (Zheng et al., 2006). Soybean protein peptide (SPP) is a mixed oligopeptide prepared through protease hydrolysis or microbial fermentation (Zhang J. et al., 2020). It has no anti-nutritional factors and is rich in amino acids, low-molecular-weight small peptide and special nutrients (Puchalska et al., 2014). In addition, it is easy to digest and absorb, and has physiologically active substances that promote fat metabolism (Huang, 2015). Previous studies showed that SPP had many advantages, including antioxidant (Ma et al., 2016), cholesterol-lowering and immune-enhancing activities (Zhao Z. X. et al., 2016; Cheng et al., 2017; Zhang Y. J. et al., 2020).
Pompano T. ovatus, a valuable food fish with tender flesh and delicious flavor, is mainly distributed in the warm tropical waters of the Pacific Ocean, Indian Ocean, and Atlantic Ocean (Tutman et al., 2004; Li M. M. et al., 2020). This fish thrives in tropical and subtropical climates due to its delicious flesh, rapid growth, simple feeding habits and high survival rate $(\mathrm{Qu}$ et al., 2014; Zhang et al., 2019). The annual production of T. ovatus in China has exceeded 100,000 tons in 2020, promising candidates for intensive aquaculture in Southern China with annual production of around 120,000 tons (Li M. et al., 2020). Plant protein sources in Pompano T. ovatus feed, including soybean meal (Wu et al., 2010; Niu et al., 2016), fermented soybean meal (Lin et al., 2012), rapeseed meal (Kou et al., 2015), and cottonseed protein concentrate (Shen et al., 2019), have attracted considerable interest. Meanwhile, SPP has not been reported. In this experiment, juvenile Pompano T. ovatus was used as a research target, and different proportions of FM were substituted with SPP to prepare iso-nitrogenous and isolipid test feeds. This study aimed to investigate the effects of the replacement of FM with SPP on growth, histomorphology, liver fat metabolism, and intestinal immune function for juvenile Pompano T. ovatus.

\section{MATERIALS AND METHODS}

\section{Diet Formulation and Preparation}

The experimental diet was formulated to provide $41.00 \%$ of crude protein (Table 1), and the dietary amino acid composition was shown (Table 2). The proximate compositions and amino acid composition of FM and SPP used in this study were presented in Table 3. The proportion of SPP with a relative molecular mass of less than 1,000 Da was 100\%, provided by Yisheng Biotechnology Company (Yangjiang, Guangdong, China). Five iso-nitrogenous and iso-lipidic experiment diets were formulated to contain 0 , $5.45,10.90,21.78$, and $27.23 \%$ of SPP by replacing $0,14.29,28.57$, 57.14 , and $71.42 \%$ of FM, respectively. Reduction in feed by $0 \%$ (FM, control group), 5\% (S5), 10\% (S10), 20\% (S20), and 25\% (S25) FM, respectively. FM and soybean meal were the main sources of protein in the diet. Fish oil, soybean oil, and soybean lecithin oil were the lipid sources.

All raw material was crushed through a 60-mesh sieve, mixed thorough a V-type vertical mixer (JS-14S; Zhejiang Zhengtai Electric Co., Ltd.), followed by adding with oil and water, and then pelleted $(2.5 \mathrm{~mm}$ diameter) making use of a double screw extruder (F-75; South China University of Technology). After the prepared experimental feed was naturally dried to about $10 \%$ moisture, it was sealed in a vacuum-packed bag and stored at $-20^{\circ} \mathrm{C}$ until it was fed (He et al., 2021; Lin et al., 2021).

\section{Experimental Animals and Breeding Management}

The experiment was conducted at an experimental site in Zhanjiang, Guangdong, China. Juvenile T. ovatus was procured from a seedling farm in Hainan Province for this investigation. Live fish were transported from Hainan to Guangdong using live fish transport techniques and cultured in a floating cage 
TABLE 1 | Formulation and proximate composition of experimental diet (\%, dry matter).

\begin{tabular}{|c|c|c|c|c|c|}
\hline \multirow[t]{2}{*}{ Ingredients } & \multicolumn{5}{|c|}{ Diets } \\
\hline & FM & S5 & $\mathrm{S} 10$ & $\mathrm{~S} 20$ & S25 \\
\hline Brown fish meal & 35.00 & 30.00 & 25.00 & 15.00 & 10.00 \\
\hline Soybean protein peptide & 0.00 & 5.45 & 10.90 & 21.78 & 27.23 \\
\hline Soybean meal & 20.00 & 20.00 & 20.00 & 20.00 & 20.00 \\
\hline Peanut meal & 4.00 & 4.00 & 4.00 & 4.00 & 4.00 \\
\hline Corn gluten meal & 4.00 & 4.00 & 4.00 & 4.00 & 4.00 \\
\hline Wheat flour & 20.00 & 20.00 & 20.00 & 20.00 & 20.00 \\
\hline Calcium dihydrogen phosphate & 1.50 & 1.50 & 1.50 & 1.50 & 1.50 \\
\hline Vitamin C & 0.05 & 0.05 & 0.05 & 0.05 & 0.05 \\
\hline Choline chloride & 0.30 & 0.30 & 0.30 & 0.30 & 0.30 \\
\hline Soybean lecithin oil & 1.50 & 1.50 & 1.50 & 1.50 & 1.50 \\
\hline Soybean oil + fish oil $(1: 1)$ & 4.18 & 4.35 & 4.53 & 4.89 & 5.07 \\
\hline Vitamin premix ${ }^{a}$ & 0.50 & 0.50 & 0.50 & 0.50 & 0.50 \\
\hline Mineral premix ${ }^{b}$ & 0.50 & 0.50 & 0.50 & 0.50 & 0.50 \\
\hline Methionine & 0.41 & 0.47 & 0.53 & 0.65 & 0.71 \\
\hline Lysine & 0.24 & 0.34 & 0.44 & 0.64 & 0.74 \\
\hline Threonine & 0.00 & 0.03 & 0.06 & 0.13 & 0.16 \\
\hline Arginine & 0.13 & 0.12 & 0.12 & 0.11 & 0.10 \\
\hline Microcrystalline cellulose & 7.69 & 6.89 & 6.07 & 4.46 & 3.64 \\
\hline Total & 100.00 & 100.00 & 100.00 & 100.00 & 100.00 \\
\hline \multicolumn{6}{|l|}{ Nutrient levels } \\
\hline Crude protein $^{c}$ & 40.48 & 40.72 & 40.43 & 40.71 & 40.21 \\
\hline Crude lipid ${ }^{C}$ & 7.97 & 8.27 & 8.26 & 8.16 & 8.02 \\
\hline Crude ashc & 8.76 & 8.37 & 7.84 & 6.97 & 6.41 \\
\hline
\end{tabular}

The vitamin premix: vitamin A 500,000 $\mathrm{U} / \mathrm{kg}$; vitamin $D_{3}$ 100,000 $\mathrm{l} / \mathrm{kg}$; vitamin E 4,000 mg/kg; vitamin $K_{3} 1,000 \mathrm{mg} / \mathrm{kg} ;$ vitamin $B 1500 \mathrm{mg} / \mathrm{kg}$; vitamin $B_{2}$ $1,000 \mathrm{mg} / \mathrm{kg}$; vitamin $B_{6} 1,000 \mathrm{mg} / \mathrm{kg}$; vitamin $B_{12} 2.0 \mathrm{mg} / \mathrm{kg}$; nicotinic acid 4,000 mg/kg; D-calcium pantothenate 2,000 mg/kg; folic acid $100 \mathrm{mg} / \mathrm{kg}$; biotin $10.0 \mathrm{mg} / \mathrm{kg}$; vitamin C 15,000 $\mathrm{mg} / \mathrm{kg}$.

bMineral mixture: Fe 10,000 mg/kg; Cu $300 \mathrm{mg} / \mathrm{kg} ; \mathrm{Zn} \mathrm{5,000} \mathrm{mg/kg;} \mathrm{Mn}$ 1,200 mg/kg; / 80 mg/kg; Se 30 mg/kg; Co 20 mg/kg.

${ }^{c}$ Crude protein, crude lipid and ash contents were measured values.

(length: $5 \mathrm{~m}$; width: $5 \mathrm{~m}$; and height: $5 \mathrm{~m}$ ) (Harmon, 2009; Zhang et al., 2021). Before the experiment, all fish were fed commercial diets (Zhanjiang Yuehai Feed Co. Ltd., Guangdong, China; crude protein $42 \%$, crude lipid $8 \%$ ) for a week to acclimatize to the conditions. At this experiment, the total number of the experimental fish was 600, and there were 40 fish (initial body weight: $39.88 \pm 0.15 \mathrm{~g}$ ) in each floating cage (length: $1 \mathrm{~m}$; width: $1 \mathrm{~m}$; and height: $2 \mathrm{~m}$ ), respectively. The 15 groups were randomly assigned to the five test diets, with three replicates each. All fishes were fed twice daily (7:00 and 17:00) to visual satiety for 8 weeks. During the experiment, water temperature ranged from 29.0 to $31.0^{\circ} \mathrm{C}$, the salinity was $24-26 \%$ and the dissolved oxygen was not less than $6 \mathrm{mg} / \mathrm{L}$.

All procedures involving live animals were approved by the Guangdong Ocean University Institutional Animal Care and Use Committee.

\section{Sample Collection}

Fish samples were kept fast for $24 \mathrm{~h}$ before collection at the end of trial and anesthetized with MS-222 (1:10,000; Zhou
TABLE 2 | Amino acid composition of the experimental diet (\% dry matter).

\begin{tabular}{|c|c|c|c|c|c|}
\hline & \multicolumn{5}{|c|}{ Experimental diets } \\
\hline & FM & S5 & S10 & $\mathrm{S} 20$ & S25 \\
\hline \multicolumn{6}{|l|}{$\mathrm{EAA}^{\mathrm{a}}$} \\
\hline Threonine & 1.48 & 1.51 & 1.50 & 1.56 & 1.52 \\
\hline Valine & 1.82 & 1.80 & 1.79 & 1.72 & 1.74 \\
\hline Methionine & 1.05 & 1.03 & 0.98 & 0.81 & 0.82 \\
\hline Leucine & 3.04 & 3.07 & 3.09 & 3.06 & 3.08 \\
\hline Phenylalanine & 1.76 & 1.78 & 1.79 & 1.87 & 1.84 \\
\hline Lysine & 2.59 & 2.62 & 2.65 & 2.64 & 2.63 \\
\hline Histidine & 1.11 & 1.10 & 1.07 & 1.08 & 1.02 \\
\hline \multicolumn{6}{|l|}{ NEEA ${ }^{b}$} \\
\hline Aspartic acid & 3.49 & 3.57 & 3.61 & 3.75 & 3.74 \\
\hline Serine & 1.59 & 1.66 & 1.64 & 1.78 & 1.68 \\
\hline Glutamic acid & 6.68 & 6.85 & 7.01 & 7.37 & 7.39 \\
\hline Glycine & 1.98 & 1.93 & 1.86 & 1.75 & 1.70 \\
\hline Alanine & 2.19 & 2.14 & 2.03 & 1.96 & 1.84 \\
\hline Isoleucine & 1.59 & 1.59 & 1.62 & 1.58 & 1.64 \\
\hline Tyrosine & 1.18 & 1.20 & 1.10 & 1.18 & 1.16 \\
\hline Proline & 2.41 & 2.44 & 2.44 & 2.51 & 2.52 \\
\hline Arginine & 2.03 & 2.08 & 2.07 & 2.14 & 2.07 \\
\hline Cystine & 0.41 & 0.45 & 0.46 & 0.45 & 0.45 \\
\hline
\end{tabular}

${ }^{a} E A A$, essential amino acids; ${ }^{b} N E A A$, non-essential amino acids.

et al., 2019). The fish samples of each experimental group were calculated and weighed, and it was determined that weight gain ratio, the survival rate, specific growth rate and feed conversion ratio. Afterward, three fish samples of each floating cage were randomly used to test the body length and body weight to make a calculation of the hepatosomatic index, condition factor and viscerosomatic index, and then stored at $-20^{\circ} \mathrm{C}$ to detect the whole-body composition (Wang et al., 2018; Wu et al., 2021). Blood samples were gotten from the tail veins of seven randomly selected fish samples from each floating cage, and then stored at $4^{\circ} \mathrm{C}$ for $12 \mathrm{~h}$ (Chen et al., 2016; Cai et al., 2020). After centrifuged $\left(4,000 \times \mathrm{g}, 4^{\circ} \mathrm{C}, 10 \mathrm{~min}\right)$, the serum of fish samples was obtained and immediately preserved at $-80^{\circ} \mathrm{C}$ for analyzing serum biochemical (Wang J. et al., 2020). Furthermore, the fish liver and intestine samples were quickly removed, one part was stored in 4\% paraformaldehyde solution for histological analysis (Cai et al., 2021), whereas the others were stored in RNA-later at $-80^{\circ} \mathrm{C}$ before RNA isolation.

\section{Formula for Calculations}

Weight gain rate $(\mathrm{WGR}, \%)=100 \times[$ final body weight $(\mathrm{g})-$ initial body weight $(\mathrm{g})] /$ initial body weight $(\mathrm{g})$;

Feed coefficient rate $(\mathrm{FCR})=$ feed intake $(g) /[$ final body weight (g) - initial body weight (g)]; 
TABLE 3 | Proximate composition of the fishmeal and soy protein peptide (\% dry matter).

\begin{tabular}{lcc}
\hline Ingredient & FM & SPP \\
\hline Nutrients & & \\
Moisture & 8.15 & 8.00 \\
Crude protein & 70.03 & 60.87 \\
Crude lipid & 7.57 & 3.68 \\
Amino acids & & \\
Aspartate & 5.80 & 4.80 \\
Threonine & 2.76 & 1.54 \\
Serine & 2.51 & 2.01 \\
Glutamic & 8.73 & 7.75 \\
Glycine & 3.99 & 1.68 \\
Alanine & 4.22 & 1.82 \\
Cystine & 0.57 & 0.00 \\
Valine & 3.04 & 1.74 \\
Methionine & 1.94 & 0.15 \\
Isoleucine & 2.73 & 1.67 \\
Leucine & 2.28 & 2.99 \\
Tyrosine & 3.75 & 1.30 \\
Phenylalanine & 2.51 & 1.97 \\
Lysine & 2.24 & 2.43 \\
Histidine & 2.66 & 1.96 \\
Arginine & 5.18 & \\
Proline & & \\
\hline & & \\
\hline
\end{tabular}

Specific growth rate $($ SGR, \%) $=100 \times[\ln ($ final body weight $(\mathrm{g}))$

$-\ln$ (initial body weight (g))]

/days;

Survival rate $(\mathrm{SR}, \%)=100 \times($ final fish number $/$

initial fish number);

Hepatic somatic indices (HSI, \%) $=100 \times$ hepatic weight $(\mathrm{g}) /$ body weight (g);

Condition factor $\left(\mathrm{CF}, \mathrm{g} / \mathrm{cm}^{3}\right)=100 \times[$ body weight $(\mathrm{g})] /$

[body length $(\mathrm{cm})]^{3}$;

Daily feed intake (DFI, \%/days) $=100 \times$ feed intake $/$

[(initial body weight +

final body weight) $/ 2$

$\times$ experimental period].

\section{Chemical Analyses}

The ingredients of the experimental diets and fish samples (crude protein, crude lipid, moisture, and ash) were measured by using standard methods AOAC (Association of Official Analytical Chemists [AOAC], 2005).

The total protein (TP), triglyceride (TG), total cholesterol (T-CHO), and glucose (GLU) in serum were assayed using an automatic blood analyzer (Hitachi 7020, Hitachi Science Systems, Japan), following a previously described method of Gyan et al. (2020).

The immune enzyme activities were determined by using a detection kit (Nanjing Jian Cheng Bioengineering Institute, China). The total superoxide dismutase (T-SOD) was measured by the xanthine oxidase method according to Wang et al. (2011). The activity of glutathione peroxidase (GSH-Px) was determined using the xanthine oxidase method (Ma et al., 2014). The total antioxidant capacity (T-AOC) was measured by Yang et al. (2017). The malondialdehyde (MDA) content was determined as described by Liang et al. (2020a) and Lin et al. (2020). The acid phosphatase (ACP) and alkaline phosphatase (AKP) were determined following Zhu et al. (2012) and Zhu et al. (2021). The lysozyme (LYZ) activity was assayed according to Liu et al. (2021).

\section{Real-Time PCR Analysis of the Organization}

Total RNA from the liver and hind intestines was extracted with an RNA extraction kit (TransZol Up Plus RNA Kit, Beijing, China). PrimeScript ${ }^{\mathrm{TM}}$ RT-PCR Kit (TaKaRa, Kusatsu, Japan) was used to synthesize complementary DNA (cDNA) according to the manufactures' instructions. The PCR primers were listed in Table 4. The PCR cycling protocol by Liang et al. (2020b) was used, and all the real-time PCR reactions were performed on a Roche LightCycler480II (Switzerland) using an SYBR @ Premix Ex Taq ${ }^{\mathrm{TM}}$ Kit (Takara). The relative mRNA expressions were calculated using the $2^{-\Delta \Delta \mathrm{CT}}$ method.

\section{Histological Morphology}

The intestinal tracts and livers of the fish were quickly removed, and one part was stored in $4 \%$ paraformaldehyde solution for histological analysis using hematoxylin-eosin (H\&E) (MartínezLlorens et al., 2012). The tissue sections were observed and photographed under an electron microscope scanner (VS 120S6, Olympus, Norway) with villi length and muscle thickness measured according to the method of Wang J.X. et al. (2020). Sections from each floating cage were randomly measured for villi lengths and muscle layer thicknesses (Lin et al., 2019).

\section{Statistical Analysis}

All data were subjected to ANOVA using SPSS 21.0 (SPSS Inc., Chicago, IL, United States). Tukey's HSD multiple comparisons were performed in the case of a significant overall difference between the experimental group and the control $(P<0.05)$. The results were presented as the mean \pm SEM (standard error of the mean). 
TABLE 4 | Sequences of primers used for real-time quantitative PCR.

\begin{tabular}{|c|c|c|}
\hline Gene name & Primer sequence $\left(5^{\prime}-3^{\prime}\right)$ & References \\
\hline$c 4$ & $\begin{array}{l}\text { F-TGGAGAAAAAGTTAAAGGGGC } \\
\text { R-CAGGAAGGAAGTATGAGCGAGT }\end{array}$ & Tan et al., 2018 \\
\hline$n f-\kappa b$ & $\begin{array}{l}\text { F-TGCGACAAAGTCCAGAAAGAT } \\
\text { R-CTGAGGGTGGTAGGTGAAGGG }\end{array}$ & Zhou et al., 202 \\
\hline il-8 & $\begin{array}{l}\text { F-GAGAAGCCTGGGAATGGA } \\
\text { R-GAGCCTCAGGGTCTAAGCA }\end{array}$ & Zhou et al., 2020 \\
\hline il-10 & $\begin{array}{l}\text { F-CTCCAGACAGAAGACTCCAGCA } \\
\text { R-GGAATCCCTCCACAAAACGAC }\end{array}$ & Tan et al., 2017 \\
\hline$i l-1 \beta$ & $\begin{array}{l}\text { F-CGGACTCGAACGTGGTCACATTC } \\
\text { R-AATATGGAAGGCAACCGTGCTCAG }\end{array}$ & Xie et al., 2020 \\
\hline cptl & $\begin{array}{l}\text { F-CTITAGCCAAGCCCTTCATC } \\
\text { R-CACGGTTACCTGTTCCCTCT }\end{array}$ & Liu et al., 2018 \\
\hline fsan & $\begin{array}{l}\text { F-GAAGGAGAGGGGGTGGAGTC } \\
\text { R-GTGTGAAGGTGGAGGGTGTG }\end{array}$ & Liu et al., 2018 \\
\hline apob100 & $\begin{array}{l}\text { F-AAAAGCCACAAGACGAAAGCA } \\
\text { R-GAAGCAGCAAAAGGCAGAGC }\end{array}$ & Liu et al., 2018 \\
\hline srebp-I & $\begin{array}{l}\text { F-GAGCCAAGACAGAGGAGTGT } \\
\text { R-GTCCTCTTGTCTCCCAGCTT }\end{array}$ & Li et al., 2020 \\
\hline fabpl & $\begin{array}{l}\text { F-AGTCATTGTCTGGGGAGGG } \\
\text { R-GTCAAGGCGGTGGTTCA }\end{array}$ & Liu et al., 2018 \\
\hline$\beta$-actin & $\begin{array}{c}\text { F-TACGAGCTGCCTGACGGACA } \\
\text { R-GGCTGTGATCTCCTTCTGC }\end{array}$ & Xie et al., 2019 \\
\hline
\end{tabular}

c4, complement 4; nf-кb, nuclear factor kappa B; il-8, interleukin 8; il-10,

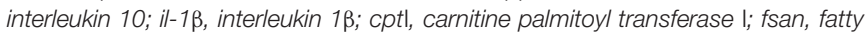
acid synthesis; apob100, apolipoprotein B-100; srebp-I, sterol-regulatory element binding protein-l; fabpl, fatty acid binding protein I.

\section{RESULTS}

\section{Growth Performance and Whole-Body Composition}

No significant differences in IBW, WGR, SGR, SR, FCR, CF, and DFI were found among the groups $(P>0.05$; Table 5). As SPP increased, VSI firstly decreased and then increased, and the S10 group was significantly lower than the FM group $(P<0.05)$. As SPP level increased, HSI gradually decreased and was significantly lower in the S10, S20, and S25 groups than in the FM group $(P<0.05)$.

The results of the whole-body composition for juvenile pompano $T$. ovatus are shown in Table 6. No significant differences were found in the whole-body composition among juvenile pompano $T$. ovatus fed with different amounts of dietary SPP $(P>0.05)$.

\section{Serum Antioxidant and Immune Enzyme Activities}

As SPP level increased, AKP activity showed an increasing trend followed by a decreasing trend (Table 7; $P<0.05$ ). AKP activity in the S10 group was significantly higher than that in the control group $(P<0.05)$. ACP activity showed an increasing tendency followed by a decreasing trend, but the difference among the groups was not significant $(P>0.05)$. LYZ activity increased and then decreased, showing a trend change in line with AKP activity. LYZ activity in the S10 group was significantly higher than that in the control group $(P<0.05)$. According to the second-order polynomial analysis model of LYZ activity, the SPP replacement level of juvenile pompano T. ovatus was $11.82 \%$, corresponding to SPP replacement level (Figure 1).

T-SOD activity in the S5, S10, and S20 groups was not significantly different from that of the control group, or the high substitution group (S25) had significantly lower T-SOD activity than that in the control group. The GSH-Px activity showed an increase followed by a decrease. GSH-Px activity in the S10 and S20 groups was significantly higher than in the FM group $(P<0.05)$. As SPP increased, MDA content showed a gradually decreasing trend, and the groups in S10, S20, and S25 were significantly lower than that in the FM group $(P<0.05)$. No significant difference in T-AOC activity was found among the groups $(P>0.05)$, but T-AOC activity was higher in the substitution groups than in the FM group.

\section{Serum Biochemical Indices}

TP content in the S5, S10, and S20 groups were significantly higher than that in the FM group (Table 8, $P<0.05$ ), but difference in TP content between the S25 and FM groups was not significant $(P>0.05)$. As SPP increased, TG levels gradually decreased, and the FM groups had the highest TG levels $(P<0.05)$. T-CHO and TG levels in the experimental group gradually decreased and were significantly lower than those in the FM group $(P<0.05)$. No significant differences in glucose content were found among the groups $(P>0.05)$.

\section{Liver and Intestinal Morphology}

Observation of liver tissue (Figure 2) showed that serious vacuolation occurred in the FM group, but the cell boundaries of FM, S5, and S10 groups were obvious, and the rate of intracellular vacuolization decreased. The nuclei of hepatocytes in the S20 group began to gradually lyse or disappear, and the nuclei of hepatocytes increased in spacing and showed blurred outlines after cell disintegration.

We stained the liver with oil red to observe fat deposition in the liver (the fat was stained red, Figure 3). Fat deposition tended to decrease with increasing SPP level. The fat droplets in the FM group were large and dense, whereas the fat droplets were significantly smaller and the deposition sites were more dispersed in the experimental groups.

The hind-gut structure data of juvenile T. ovatus are provided (Figures 4, 5). As SPP level increased, villus length (VL) increased first and then decreased and was significantly higher in the S10 group than in the FM group $(P<0.05)$. The trend of muscle thickness (MT) was in line with that of VL. All substitution groups were significantly higher than the FM group $(P<0.05)$, and the S10 group was higher than all other groups.

\section{Expression of Lipid Metabolism-Related Genes in the Liver}

In the present study, the expression of lipid metabolismrelated genes in the liver were analyzed (Figure 6). The hepatic carnitine palmitoyl transferase I (cptI) mRNA levels in the S5 and S10 groups were significantly higher than those in the other groups $(P<0.05)$. The fatty acid synthesis (fasn) mRNA 
TABLE 5 | Growth performance and biometry for juvenile Trachinotus ovatus fed the experimental diet.

\begin{tabular}{|c|c|c|c|c|c|}
\hline \multirow[t]{2}{*}{ Parameters } & \multicolumn{5}{|c|}{ Experimental diets } \\
\hline & FM & S5 & $\mathrm{S} 10$ & $\mathrm{~S} 20$ & $\mathrm{~S} 25$ \\
\hline IBW (g) & $39.97 \pm 0.21$ & $39.94 \pm 0.27$ & $39.91 \pm 0.08$ & $39.75 \pm 0.14$ & $39.88 \pm 0.18$ \\
\hline WGR (\%) & $117.67 \pm 3.45$ & $118.10 \pm 4.09$ & $117.70 \pm 3.24$ & $111.82 \pm 0.79$ & $114.76 \pm 1.04$ \\
\hline $\operatorname{SGR}(\% / d)$ & $1.39 \pm 0.03$ & $1.39 \pm 0.03$ & $1.38 \pm 0.04$ & $1.34 \pm 0.01$ & $1.39 \pm 0.04$ \\
\hline FCR & $2.43 \pm 0.10$ & $2.37 \pm 0.10$ & $2.39 \pm 0.15$ & $2.56 \pm 0.05$ & $2.53 \pm 0.07$ \\
\hline $\mathrm{SR}(\%)$ & $99.17 \pm 1.44$ & $100.00 \pm 0.00$ & $99.17 \pm 1.44$ & $98.33 \pm 2.89$ & $99.17 \pm 1.44$ \\
\hline VSI (\%) & $4.70 \pm 0.29^{b}$ & $4.21 \pm 0.23^{a b}$ & $4.06 \pm 0.04^{a}$ & $4.39 \pm 0.12^{a b}$ & $4.58 \pm 0.18^{b}$ \\
\hline HSI (\%) & $0.99 \pm 0.12^{b}$ & $0.98 \pm 0.07^{b}$ & $0.65 \pm 0.03^{a}$ & $0.54 \pm 0.05^{a}$ & $0.57 \pm 0.03^{a}$ \\
\hline $\mathrm{CF}\left(\mathrm{g} / \mathrm{cm}^{3}\right)$ & $4.31 \pm 0.04$ & $4.35 \pm 0.07$ & $4.32 \pm 0.14$ & $4.55 \pm 0.25$ & $4.33 \pm 0.06$ \\
\hline DFI (\%/days) & $3.15 \pm 0.07$ & $3.14 \pm 0.06$ & $3.16 \pm 0.10$ & $3.23 \pm 0.02$ & $3.21 \pm 0.04$ \\
\hline
\end{tabular}

Data are mean \pm S.E.M. $(n=3)$. Values in the same row with different superscripts represent significant difference $(P<0.05)$.

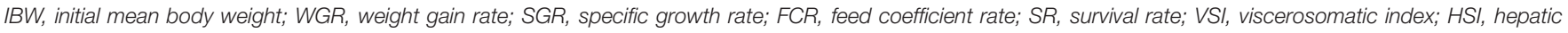
somatic indices; CF, condition factor; DFI, daily feed intake.

TABLE 6 | The composition of whole body for juvenile Trachinotus ovatus fed the experimental diet (\% dry matter).

Parameters

\begin{tabular}{|c|c|c|c|c|c|}
\hline & FM & S5 & S10 & $\mathrm{S} 20$ & S25 \\
\hline Moisture & $68.91 \pm 0.94$ & $69.53 \pm 0.56$ & $69.28 \pm 0.85$ & $69.75 \pm 0.34$ & $67.37 \pm 1.44$ \\
\hline Crude protein & $59.04 \pm 0.64$ & $60.16 \pm 0.50$ & $61.31 \pm 0.39$ & $61.06 \pm 0.79$ & $59.05 \pm 1.77$ \\
\hline Crude lipid & $27.56 \pm 0.47$ & $27.15 \pm 1.38$ & $26.96 \pm 2.92$ & $25.79 \pm 1.32$ & $27.53 \pm 2.98$ \\
\hline Crude ash & $13.32 \pm 0.21$ & $13.30 \pm 0.44$ & $12.69 \pm 0.10$ & $14.16 \pm 0.34$ & $12.85 \pm 1.52$ \\
\hline
\end{tabular}

Data are mean \pm S.E.M. $(n=3)$. Values in the same row with different superscripts represent significant difference $(P<0.05)$.

level was significantly down-regulated after the replacement of FM with SPP in compound feed $(P<0.05)$. The S25 group had significantly lower fatty acid-binding protein I (fabpI) and apolipoprotein B-100 (apob100) mRNA levels than the FM group $(P<0.05)$. No significant difference in sterol-regulatory elementbinding protein-I (srebp-I) mRNA level was found between the FM and replacement groups $(P>0.05)$.

\section{Expression of Intestinal Immunity-Related Genes}

The expression of intestinal immunity-related genes of juvenile T. ovatus is shown (Figure 7). The expression of genes involved in intestinal immunity-related genes, including interleukin 10 (il-10) and complement $4(c 4)$, was significantly up-regulated after FM was replaced with SPP $(P<0.05)$. As SPP level increased, interleukin $1 \beta$ (il-1 $\beta$ ) mRNA level was significantly down-regulated $(P<0.05)$. No significant difference in nuclear factor kappa B $(n f-\kappa b)$ mRNA level was observed between the FM group and the replacement groups $(P>0.05)$.

\section{DISCUSSION}

Soya bean meal has a high crude protein content and is rich in essential amino acids and widely available. The presence of anti-nutritional factors limits the use of soybean meal compared with FM (Yildirim et al., 2009). Indeed, excessive levels of plant proteins in feed can inhibit animal growth (Floreto et al., 2000).
However, fermented soy peptides are rich in organic acids, bacterial active proteins, folic acid, and B vitamins and have increased palatability (Cao et al., 2007). In the present study, the replacement of FM with SPP resulted in no significant differences in the WGR and SGR of juvenile T. ovatus cultured in floating cages under experimental conditions. We recommend that it is feasible to replace FM with SPP in compound feeds, and the studies on which is consistent with Epinephelus akaara (Zhao S. Y. et al., 2016) and Acipenser baerii (Wang et al., 2010). This may be related to the nutritional profile of SPP, which contains nutrients, such as low-molecular-weight peptides, vitamins, and other special nutrients, making up for the shortcomings of many plant proteins (Puchalska et al., 2014). Moreover, small peptides are preferentially used as energy substrates for the structural and functional development of intestinal mucosal epithelial cells, effectively promoting the development of intestinal mucosal tissues (Wang et al., 2003). In the present study, the replacement of FM with SPP significantly promoted intestinal growth. Therefore, the high content of low molecular weight peptides (Puchalska et al., 2014) and intestinal growth are responsible for the unaffected growth rate for juvenile T. ovatus.

Body composition can directly reflect animal growth and indirectly reflect feed quality (Li et al., 2009). In the present study, no significant differences in moisture content and crude protein content were found among the groups. This study is in line with the studies on Pelteobagrus fulvidraco (Jing et al., 2021) and Heterotis niloticus (Monentcham et al., 2010). As SPP increased, the body fat content of fish decreased gradually, and all groups 
TABLE 7 | Serum enzyme activity indices for juvenile Trachinotus ovatus fed the experimental diet.

\begin{tabular}{|c|c|c|c|c|c|}
\hline \multirow[t]{2}{*}{ Parameters } & \multicolumn{5}{|c|}{ Experimental diets } \\
\hline & FM & S5 & $\mathbf{S 1 0}$ & $\mathrm{S} 20$ & $\mathrm{~S} 25$ \\
\hline \multicolumn{6}{|c|}{ Serum immune ability } \\
\hline $\mathrm{AKP}(\mathrm{U} / \mathrm{L})$ & $34.01 \pm 9.19^{a}$ & $41.40 \pm 6.37^{a}$ & $51.61 \pm 6.54^{b}$ & $41.08 \pm 3.31^{a}$ & $30.24 \pm 1.96^{a}$ \\
\hline $\mathrm{ACP}(\mathrm{U} / \mathrm{L})$ & $41.37 \pm 0.71$ & $41.83 \pm 1.47$ & $41.59 \pm 3.19$ & $40.41 \pm 2.48$ & $39.94 \pm 0.71$ \\
\hline LYZ (U/mL) & $54.17 \pm 11.53^{a b}$ & $64.71 \pm 15.55^{\mathrm{ab}}$ & $117.01 \pm 4.97^{\mathrm{c}}$ & $68.92 \pm 5.29^{b}$ & $37.30 \pm 11.47^{a}$ \\
\hline \multicolumn{6}{|c|}{ Serum oxidation resistance } \\
\hline T-SOD (U/ml prot) & $35.41 \pm 4.16^{\mathrm{bc}}$ & $42.81 \pm 2.01^{c}$ & $30.95 \pm 6.85^{\mathrm{abc}}$ & $25.37 \pm 3.62^{a b}$ & $22.31 \pm 5.57^{a}$ \\
\hline GSH-Px (U/g prot) & $25.26 \pm 6.32^{a}$ & $48.42 \pm 3.65^{a b}$ & $56.84 \pm 10.94^{b}$ & $56.84 \pm 10.94^{b}$ & $44.21 \pm 12.63^{a b}$ \\
\hline T-AOC (mM) & $0.80 \pm 0.01$ & $0.82 \pm 0.04$ & $0.85 \pm 0.02$ & $0.81 \pm 0.01$ & $0.81 \pm 0.01$ \\
\hline MDA (nmol/mL) & $6.36 \pm 0.61^{b}$ & $6.06 \pm 0.30^{a b}$ & $4.85 \pm 0.30^{\mathrm{a}}$ & $4.85 \pm 0.80^{a}$ & $4.75 \pm 0.35^{a}$ \\
\hline
\end{tabular}

Data are mean \pm S.E.M. $(n=3)$. Values in the same row with different superscripts represent significant difference $(P<0.05)$.

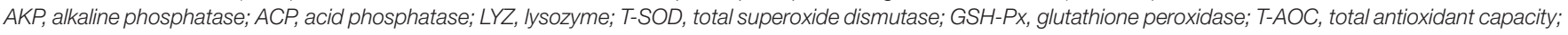
MDA, malondialdehyde.

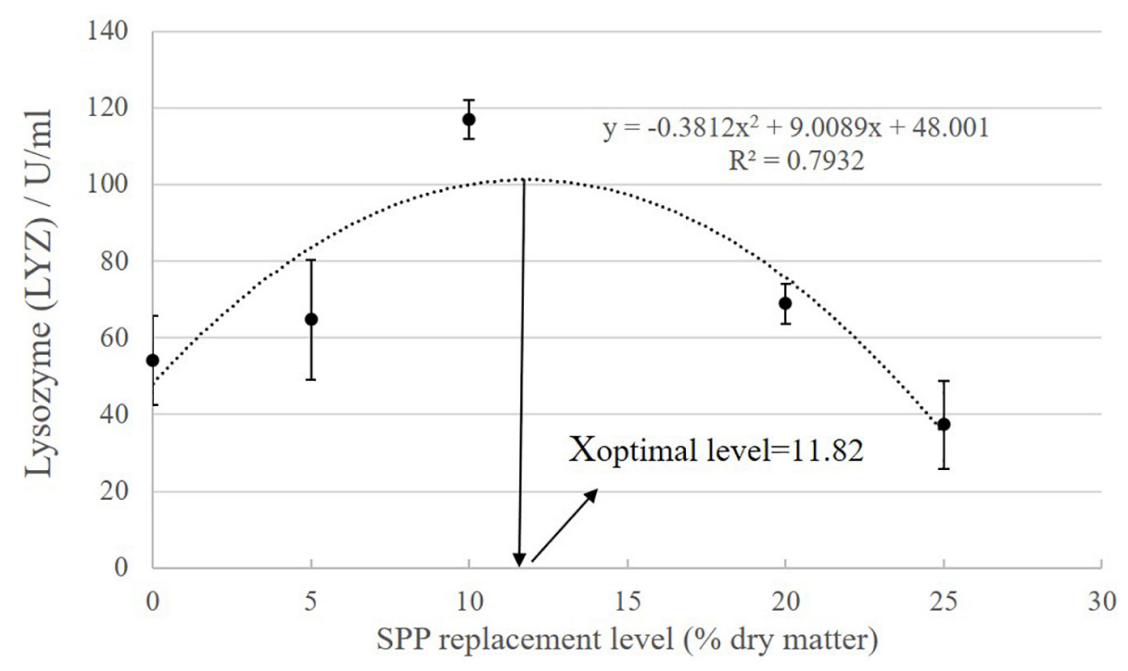

FIGURE 1 | The second-order polynomial analysis between LYZ activity and SPP replacement level, where X represents SPP replacement level for the maximum LYZ activity of juvenile pompano Trachinotus ovatus.

had lower fat content than the control group. In Platichthys stellatus (Jiang, 2013), small peptides could significantly reduce the amount of crude fat in the body. Moreover, Hou (2012) showed that SPP promoted fat and energy metabolism and inhibited fat deposition in the body. These effects are due to small peptides, which improve protein synthesis, reduce the deposition of free amino acids into fat (Boza et al., 2000), impede the absorption of fat and promote lipid metabolism (Christian, 2005). These results indicated that the replacement of FM with SPP can increase protein synthesis, promote the consumption of excess fat, and reduce fat deposition.

Condition factor, HSI, and VSI are important indices that reflect the body fat and lean status and growth status of fish (Aksnes et al., 2006a,b). In the present study, as SPP levels increased, the HSI and VSI significantly decreased, consistent with those of a hybrid grouper (Epinephelus lanceolatus $\sigma^{7} \times$ Epinephelus fuscoguttatus ; ; Jiang et al., 2015). This result may be related to the absorption mechanism of small peptides that enter the bloodstream quickly and directly without degradation. Moreover, in E. akaara, reduction in HSI was associated with increased rates of small peptide and free amino acid transport and absorption and enhanced lipid metabolism (Zhao S. Y. et al., 2016). In the present study, a significant reduction in liver fat content was observed with oil red staining. Therefore, SPP may reduce liver fat accumulation and improve liver condition.

Animal blood is an important carrier of nutrients and metabolites, and elevated levels of TG and T-CHO in the blood can be detrimental to animal health (Kim et al., 2005). Increase or decrease in TG levels can be used as an indicator of fat metabolism and liver function (He et al., 2021). Nagasawa et al. (2003) reported that SPP significantly reduces triglyceride content and fatty acid synthase mRNA levels in adipose tissues, suggesting that soy isolate controlled gene expression in adipose tissues and effectively regulated adipocyte differentiation. In the present study, T-CHO and TG levels were significantly lower 
TABLE 8 | Serum biochemical indices for juvenile Trachinotus ovatus fed the experimental diet.

\begin{tabular}{|c|c|c|c|c|c|}
\hline \multirow[t]{2}{*}{ Parameters } & \multicolumn{5}{|c|}{ Experimental diets } \\
\hline & FM & S5 & S10 & $\mathrm{S} 20$ & S25 \\
\hline $\mathrm{TP}(\mathrm{g} / \mathrm{L})$ & $6.08 \pm 1.80^{\mathrm{a}}$ & $28.64 \pm 2.01^{c}$ & $16.27 \pm 1.74^{b}$ & $12.37 \pm 3.00^{b}$ & $5.05 \pm 1.60^{a}$ \\
\hline $\mathrm{TG}(\mathrm{mmol} / \mathrm{L})$ & $2.02 \pm 0.11^{\mathrm{c}}$ & $1.38 \pm 0.14^{b}$ & $1.24 \pm 0.06^{a b}$ & $1.09 \pm 0.12^{a}$ & $1.10 \pm 0.10^{a b}$ \\
\hline $\mathrm{T}-\mathrm{CHO}(\mathrm{mmol} / \mathrm{L})$ & $23.78 \pm 2.99^{b}$ & $16.50 \pm 0.31^{a}$ & $16.35 \pm 2.00^{a}$ & $15.02 \pm 1.78^{a}$ & $12.65 \pm 1.49^{a}$ \\
\hline GLU (mmol/L) & $4.36 \pm 0.24$ & $4.32 \pm 0.31$ & $3.95 \pm 0.15$ & $4.11 \pm 0.34$ & $3.78 \pm 0.17$ \\
\hline
\end{tabular}

Data are mean \pm S.E.M. $(n=3)$. Values in the same row with different superscripts represent significant difference $(P<0.05)$.

TP, total protein; TG, triglyceride; T-CHO, total cholesterol; GLU, glucose.
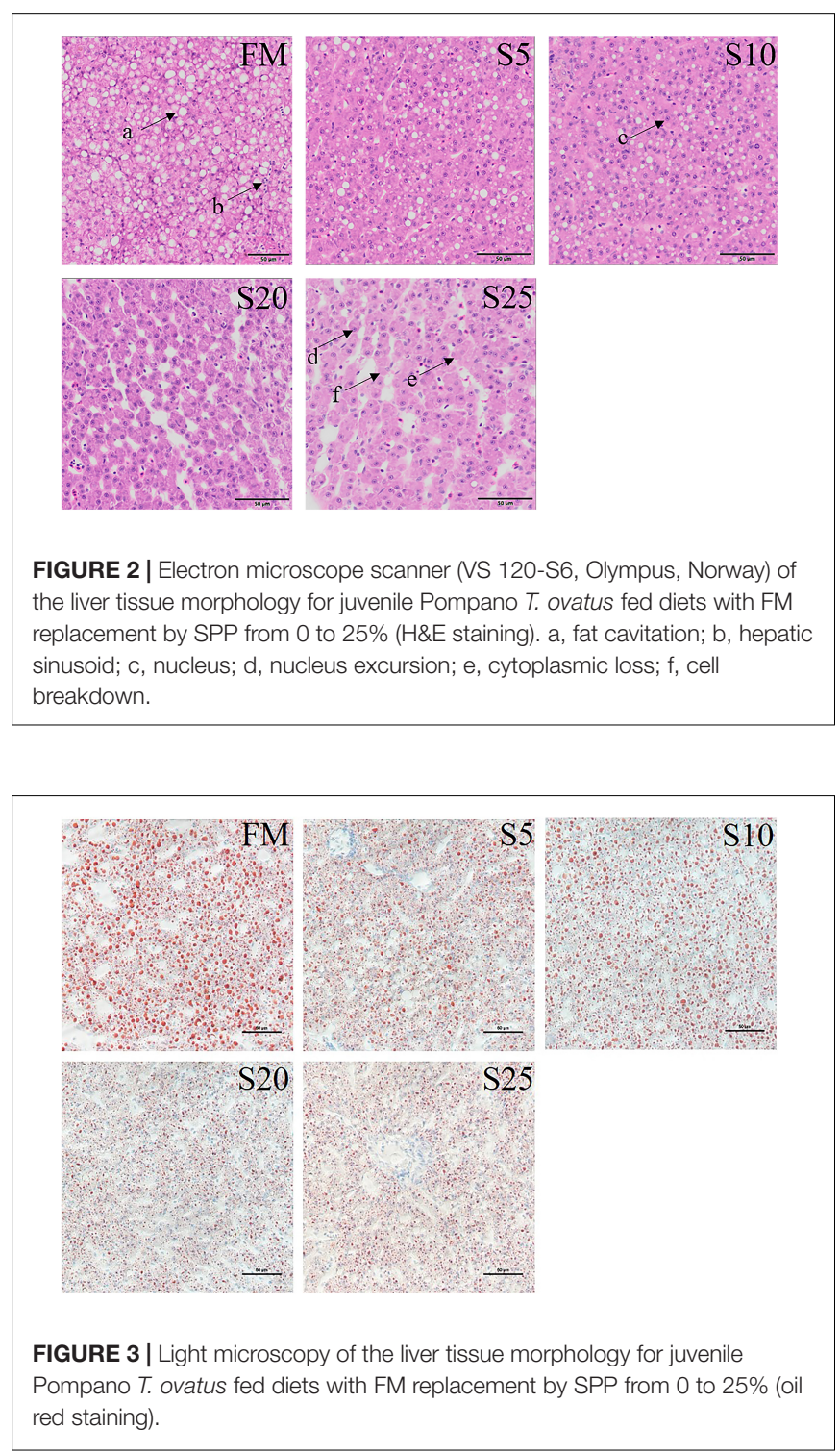

than those in the control group (FM), indicating that SPP can effectively regulate TG and T-CHO metabolism. LPYPR (LeuPro-Tyr-Pro-Arg) and VK (Val-Lys) derived from glycine in soy are important components that lower cholesterol peptides and triglycerides, respectively (Inoue et al., 2011, 2015). SPP

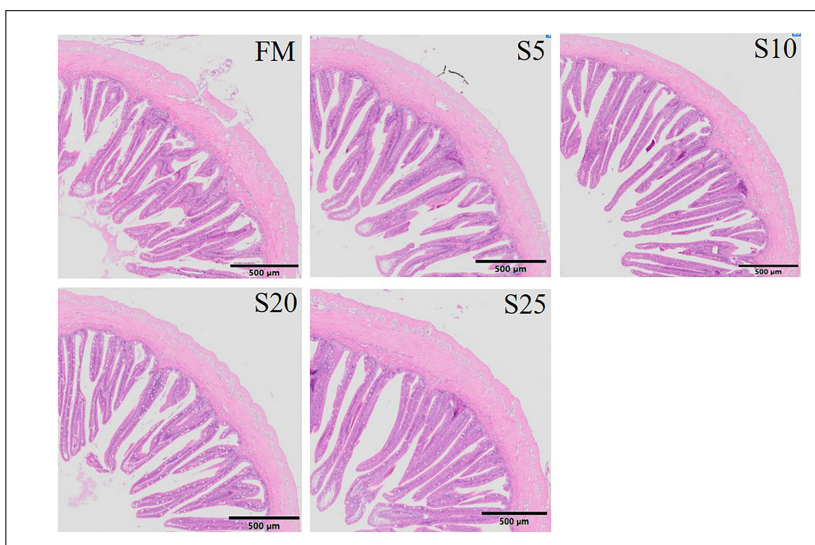

FIGURE 4 | Electron microscope scanner (VS 120-S6, Olympus, Norway) of the proximal intestine morphology for juvenile Pompano T. ovatus fed diets with FM replacement by SPP from 0 to 25\% (H\&E staining).

are more beneficial to the balanced absorption of amino acids in fish than FM.

Fish fat metabolism mainly occurs in the liver, including synthesis, catabolism, and transport, and is regulated by a multitude of factors with synergistic activities ( $\mathrm{Hu}, 2004$; Weng et al., 2012). The fasn is the key enzyme for the de novo fatty acid biosynthesis, catalyzing the synthesis of malonyl-CoA and acetyl coenzyme A into long-chain saturated fatty acids (He et al., 2021). The cptI is a key and rate-limiting enzyme that regulates the beta-oxidation of fatty acids, the main catabolic process in the body (Nilsson-Ehle et al., 1980). In the present study, the FM group had the highest liver fasn mRNA level, and $c p t$ I expression in the S5 and S10 groups was significantly up-regulated. These findings were consistent with those of Nagasawa et al. (2003). In addition, fat deposition is related to fat transport rate. Increase in very-low-density lipoprotein (VLDL) secretion rate can reduce hepatic lipid deposition (Nagayoshi et al., 1995). Hussain et al. (2008) reported that apob100 is an essential component in the assembly of VLDL particles. The fabpI can bind long-chain fatty acids for oxidation and storage through the cell membrane (Yan et al., 2015). In the present study, the S25 group had significantly lower in apob100 and fabpI expression levels than that the other groups. The morphology of the liver cells in the FM, S5, and S10 groups was normal, and fat accumulation in the liver gradually decreased. These results were in line with those of the HSI and VSI analyses. With FM decreased, liver 

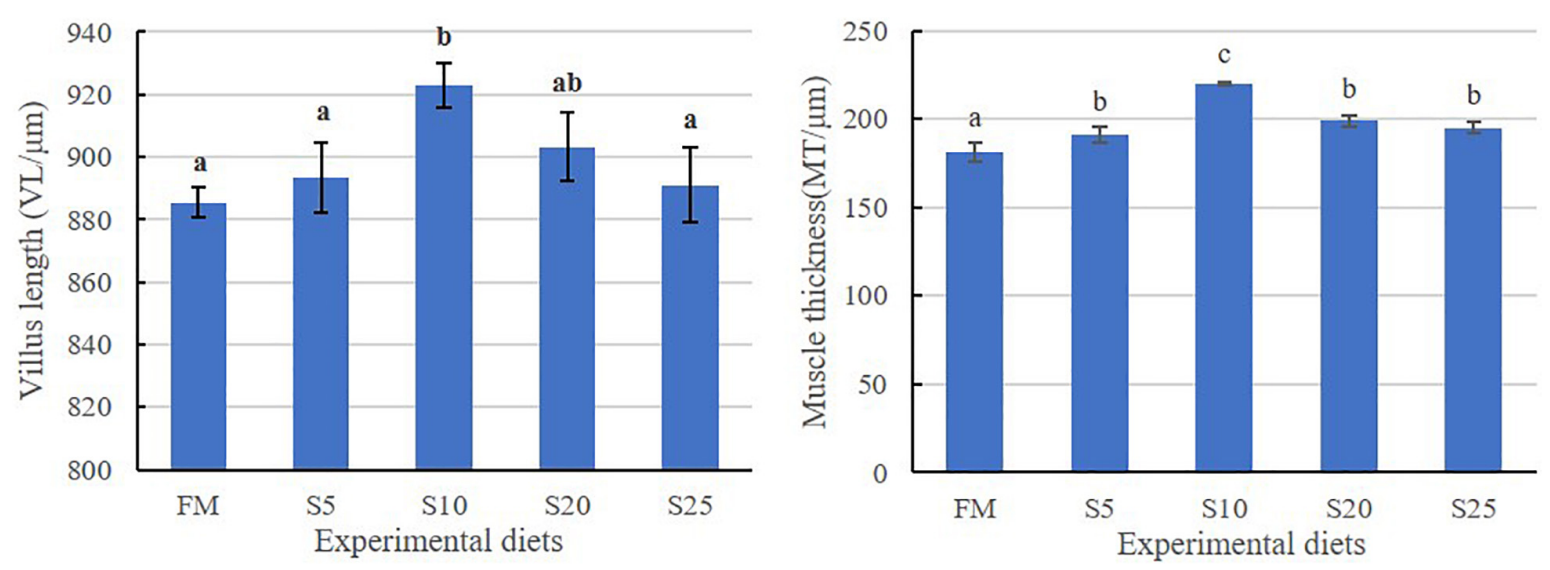

FIGURE 5 | Hindgut intestine for juvenile T. ovatus fed the experimental diet. Data are mean \pm S.E.M. $(n=3)$. Values in the same row with different superscripts represent a significant difference $(P<0.05)$.

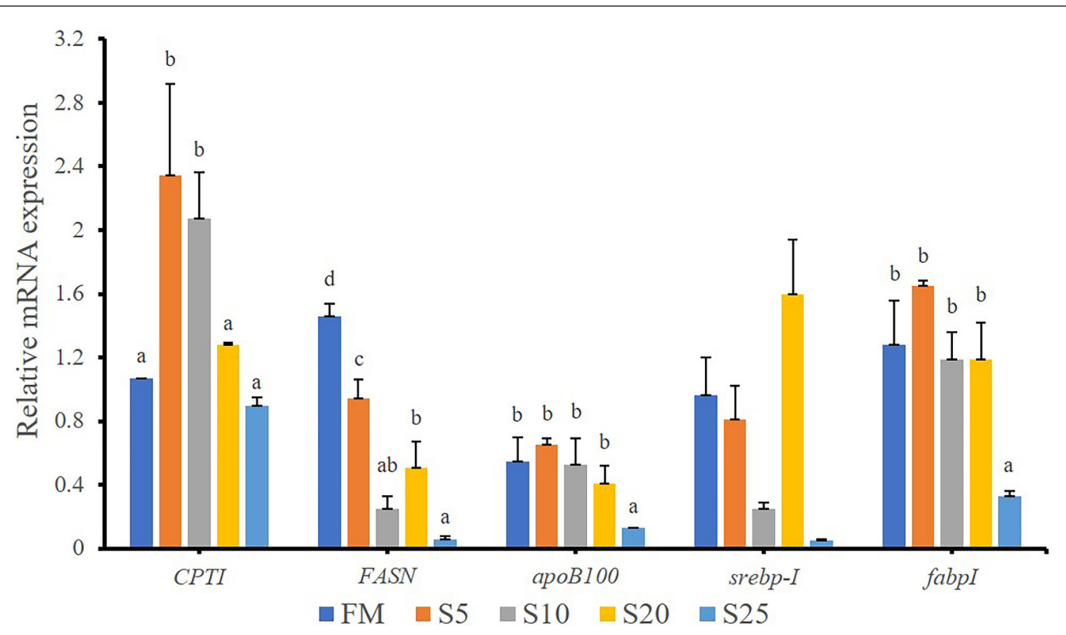

FIGURE 6 | Relative expression levels of lipid metabolism-related genes in liver for juvenile $T$. ovatus. Data are expressed as means \pm SEM. ( $n=3$ ). Different letters above a bar are statistically significant different among treatments $(P<0.05)$.

cells were seriously damaged, the cells collapsed, and the nuclei disappeared. These effects were in line with the observation on Oncorhynchus mykiss (Feng et al., 2016), Carassius auratus (Shi et al., 2015), and Lateolabrax japonicus (Hu et al., 2013). We considered that excessive soy protein peptides can damage the liver, leading to dysfunction (Zhang et al., 2002). Therefore, our observations indicated that the replacement of 10\% FM with SPP significantly promotes liver fat metabolism in grouper, reduces liver fat deposition, and improves liver condition.

The defense system can protect cells and cell membranes from oxidative damage and maintain normal physiological function (Bu et al., 2017). MDA is the oxidative end-product of free radicals acting on the peroxidation reaction of fat, and its content indirectly reflects the content of oxygen free radicals in the cells and the severity of free radical attacks (Cheng et al., 2017). In the present study, MDA content significantly decreased with increasing SPP supplementation. This result was in line with the results of Gyan et al. (2020). Deng et al. (2006) reported that soybean peptides had strong DPPH (1,1-Diphenyl2-picrylhydrazyl) radical-scavenging ability and most functional peptides with antioxidant properties were mainly concentrated in small peptides with molecular weights of lower than 5,000 Da. The molecular weights of SPP used in this experiment were mainly lower than 1,000 Da, providing a good molecular basis for antioxidant function. We suggest that SPP can inhibit free radicals and reduce the content of lipid peroxides during stress. GSH-Px is important antioxidant enzymes in fish (Cheng et al., 2017). GSH-Px catalyzes the reduction of glutathione and removes hydrogen peroxide and lipid peroxides produced during metabolism. In the present study, GSH-Px activity reached a maximum in the S10 and S20 groups significantly higher than that in the other groups. Similar results were Cyprinus carpio (Wang et al., 2014), Ctenopharyngodon idella (Zheng et al., 2012), and P. fulvidraco (Jing et al., 2021), indicating that SPP could increase antioxidant activity, and it is related to functional peptides with antioxidant properties in soy peptides 


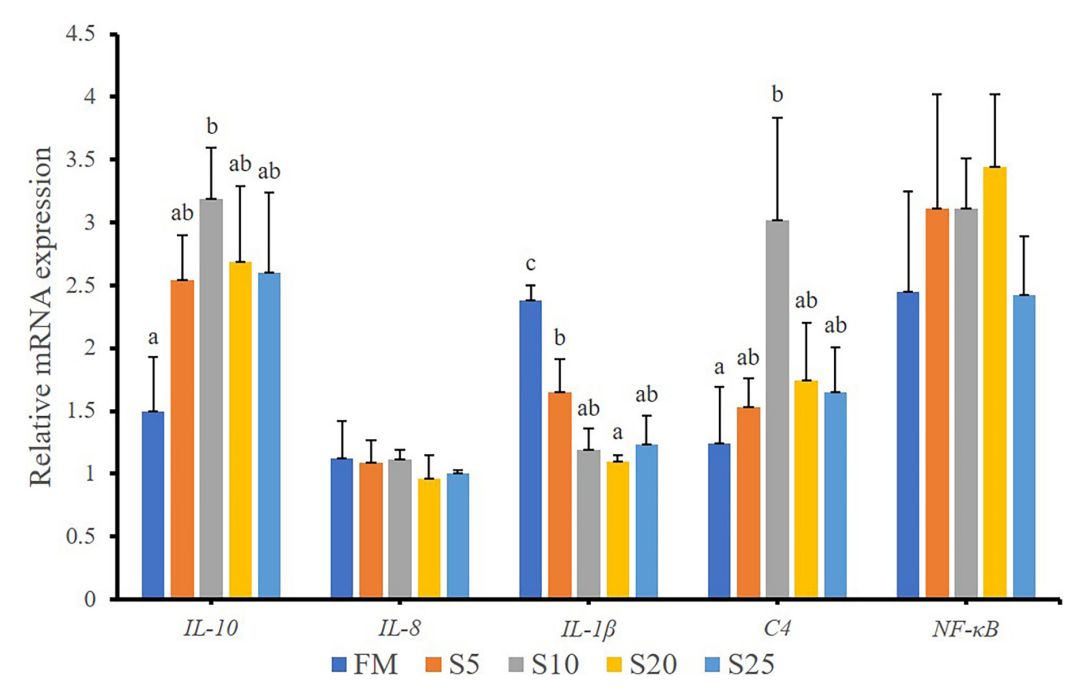

FIGURE 7 | Relative expression levels of immunity-related gene in intestine for juvenile T. ovatus. Data are expressed as means \pm SEM. Different letters above a bar are statistically significant different among treatments $(P<0.05)$.

(Deng et al., 2006). The above antioxidant indices indicate that soy protein peptides can increase the antioxidant activity for juvenile T. ovatus.

Active small peptides can participate in immune system regulation, can improve immunity, and exerts immunomodulatory effects, specifically stimulating macrophage phagocytosis and inhibiting lymphocyte proliferation (Kong et al., 2008). In serum, increases in LYZ, ACP, and AKP contribute to the immune system of aquatic organisms (Tseng et al., 2009). LYZ can hydrolyze mucopolysaccharides and catalyze the hydrolysis of glycosidic bonds in bacterial cell walls, thus causing bacterial cell walls to rupture (Xie et al., 2013). In the present study, serum LYZ activity significantly increased. The same effect was observed in L. Vannamei, indicating that the addition of small peptides significantly increases antimicrobial activity and lysozyme specific activity in sera (Lin et al., 2010). Based on the present results, the optimal SPP level that supported the most powerful immune function of juvenile $T$. ovatus was $11.82 \%$, as predicted by the LYZ activity models. ACP and AKP catalyze phosphate monostearate hydrolysis and play important roles in the immune response of the body against pathogens (Liu et al., 2004). In the present study, serum AKP activity increased first and then decreased with as the amount of replacement SPP increased in T. ovatus diet. This result was in line with the results obtained in Sardine (Ben Khaled et al., 2012) and P. fulvidraco (Zhao Z. X. et al., 2016). In addition, soy peptides help eliminate anti-nutritional factors and act as immunomodulators, inducing defense genes involved in pathogenic attacks (Pearce et al., 2010).

As an important immune organ in the animal body, the intestine provides protection against external pathogens. As reported by Zhang et al. (2020), SPP can reduce inflammation and enhance immune function by regulating the expression of pro-inflammatory cytokines, such as $i l-1 \beta$, which in turn affects the expression and secretion levels of $\mathrm{T}$ cells. The $i l-1 \beta$ plays an important role in inflammatory responses (Dinarello, 2000).
In the present study, the mRNA expression level of $i l-1 \beta$ in the intestine was significantly down-regulated as SPP replacement level increased. Moreover, the anti-inflammatory factor il-10 was significantly up-regulated in the S10 group. Complement is the main humoral component of the innate immune response and plays an essential role in the killing of microorganisms, phagocytosis, inflammatory response, immune complexes, and antibody production (Holland and Lambris, 2002). Fish can recognize and neutralize a variety of harmful microorganisms by specifically binding different forms of complement (Zarkadis et al., 2001). In the present study, the replacement of $10 \% \mathrm{FM}$ with SPP significantly up-regulated gene expression of $c 4$. The possible reasons are that small peptides are efficiently absorbed, and the amount of undigested protein in the intestine are reduced (Zheng et al., 2006). The exact mechanisms of the effects have not been explained and further studies are needed.

Among the internal organs of fish, the gut has the largest area of contact with the internal environment. The intestine is the main part of the fish that digests and absorbs nutrients (Zhou, 2012). The shape of the fold is positively correlated with nutrient absorption area ( $\mathrm{Wu}$ et al., 2010). A decrease in the height of the intestinal fold means that the intestinal tract has a smaller absorptive area and absorb lower amounts of nutrients (Wu et al., 2014). The results of the present study showed that the replacement of FM with SPP can promote the growth of intestinal villi and muscle layer. Thus, the area of intestine absorption was enlarged. The present study observed a trend in line with the study of Jiang et al. (2010), indicating that increase in intestinal absorption area and muscle layer thickness can facilitate the absorption of SPP and improve feed utilization. In addition, the replacement of FM with a high proportion of SPP can inhibit villi growth. A high proportion of FM replacement reduces the protein metabolism of fish and damages the intestinal tissue structure (Wang et al., 2017). If the proportion of a plant-based protein used to replace FM is extremely high, the 
intestinal tract of aquatic animals will be affected to some extent. This observation showed that under the present experimental conditions, the replacement of $10 \%$ FM with SPP could promote intestinal muscle thickening and wrinkled wall growth, thus improving intestinal absorption.

\section{CONCLUSION}

The replacement of FM with SPP can promote intestinal growth for nutrient absorption without affecting the growth performance of juvenile pompano T. ovatus under experimental conditions. In addition, SPP can reduce liver fat accumulation, improve liver condition, and enhance antioxidant capacity and immunity. Based on the second-order polynomial analysis model of LYZ activity, the optimal replacement SPP level for juvenile pompano T. ovatus is $11.82 \%$.

\section{DATA AVAILABILITY STATEMENT}

The raw data supporting the conclusions of this article will be made available by the authors, without undue reservation, to any qualified researcher.

\section{REFERENCES}

Aksnes, A., Hope, B., Høstmark, Ø, and Albrektsen, S. (2006a). Inclusion of Size Fractionated Fish Hydrolysate in High Plant Protein Diets for Atlantic Cod, Gadus Morhua. Aquaculture 261, 1102-1110. doi: 10.1016/j.aquaculture.2006. 07.038

Aksnes, A., Hope, B., Jönsson, E., Björnsson, B. T., and Albrektsen, S. (2006b). Size-fractionated fish hydrolysate as feed ingredient for rainbow trout (Oncorhynchus Mykiss) fed high plant protein diets. I: growth, growth regulation and feed utilization. Aquaculture 261, 305-317. doi: 10.1016/j. aquaculture.2006.07.025

Association of Official Analytical Chemists [AOAC] (2005). Official methods of analysis of the association of official analytical chemists international, 16th Edn. Washington: Association of Official Analytical Chemists.

Ben Khaled, H., Ghlissi, Z., Chtourou, Y., Hakim, A., Ktari, N., Fatma, M. A., et al. (2012). Effect of protein hydrolysates from sardinelle (Sardinella aurita) on the oxidative status and blood lipid profile of cholesterol-fed rats. Food Res. Int. 45, 60-68. doi: 10.1016/j.foodres.2011.10.003

BØGwald, J., Dalmo, R. O. Y., McQueen Leifson, R., Stenberg, E., and Gildberg, A. (1996). The Stimulatory Effect of a Muscle Protein Hydrolysate from Atlantic Cod, Gadus Morhual., on Atlantic Salmon, Salmo Salarl., Head Kidney Leucocytes. Fish Shellfish Immunol. 6, 3-16. doi: 10.1006/fsim.1996. 0002

Boza, J. J., Moënnoz, D., Vuichoud, J., Jarret, A. R., Gaudard-de-Weck, D., and Ballèvre, O. (2000). Protein hydrolysate vs free amino acid-based diets on the nutritional recovery of the starved rat. Eur. J. Nutr. 39, 237-243. doi: 10.1007/ s003940070001

Bu, X., Chen, A., Lian, X., Chen, F., Zhang, Y., Muhammad, I., et al. (2017). An Evaluation of Replacing Fish Meal with Cottonseed Meal in the Diet of Juvenile Ussuri Catfish Pseudobagrus Ussuriensis: growth, Antioxidant Capacity, Nonspecific Immunity and Resistance to Aeromonas Hydrophila. Aquaculture 479, 829-837. doi: 10.1016/j.aquaculture.2017.07.032

Cai, L. S., Wang, L., Song, K., Lu, K. L., Zhang, C. X., and Rahimnejad, S. (2020). Evaluation of protein requirement of spotted seabass (Lateolabrax maculatus) under two temperatures, and the liver transcriptome response to thermal stress. Aquaculture 516:734615. doi: 10.1016/j.aquaculture.2019.734615

\section{ETHICS STATEMENT}

The animal study was reviewed and approved by the Guangdong Ocean University Institutional Animal Care and Use Committee.

\section{AUTHOR CONTRIBUTIONS}

HL and QY designed the experiments. HL carried out the experiments and drafted the manuscript. BT, MZ, ML, and SC were accountable for some aspects (such as ingredients and sites) of the work in ensuring that experiments can be carried out properly. QY and GR reviewed and revised the manuscript. All authors contributed to the article and approved the submitted version.

\section{FUNDING}

This study was supported by the National Natural Science Foundation (31802316). The experimental funding was offered with the National Key Research and Development Program (2019YFD0900200) and Postgraduate Education Innovation Project of Guangdong Ocean University (202155).

Cai, R. J., Zhang, J., Huang, J. S., Chen, G., Zhang, J. D., Pan, C. H., et al. (2021). Effects of Low Temperature Stress on Physiology and Biochemistry of Lipid Metabolism of Juvenile Cobia, Rachycentron canadum. J. Guangdong Ocean Univ. 41, 123-130.

Cao, L., Wang, W. M., and Yang, C. T. (2007). Advances in replacement of fish meal by soy protein in aquiculture feed. Feed Industry 4, 57-61.

Chen, Q., Liu, H. Y., Tan, B. P., Dong, X. H., Chi, S. Y., Yang, Q. H., et al. (2016). Effects of Dietary Cholesterol Level on Growth Performance, Blood Biochemical Parameters and Lipid Metabolism of Juvenile Cobia (Rachycentron canadum). J. Guangdong Ocean Univ. 36, 35-43.

Cheng, Y. B., Zhang, Y. X., Dong, Z. Y., Lu, B. Y., and Wang, Y. C. (2017). Effects of Dietary Replacement of Fish Meal and Soy Protein by Wheat Gluten on Plasma Biochemical Indices and Liver Anti-Oxidative Indices of Nibea japonica and Sparus macrocephalus. Prog. Fish. Sci. 38, 106-114. doi: 10.11758/yykxjz. 20160426001

Christian, A. D. (2005). Fatty acids and expression of adipokines. Biochim. Biophy. Acta Mol. Dis. 1740, 287-292. doi: 10.1016/j.bbadis.2004.11.019

Deng, C. P., Xue, W. T., Sun, X. L., and Quan, M. H. (2006). Functional Properties of Different Molecular Weight Segments of Soybean Peptides. Food Sci. 27, 109-112.

Dinarello, C. A. (2000). Proinflammatory cytokines. Chest 118, 503-508.

Food and Agriculture Organization [FAO] (2014). The State of World Fisheries and Aquaculture 2014. Rome: FAO, 40-41.

Feng, J., Wang, P., He, J. J., Lou, Y., Dang, H., and Deng, R. (2016). Effects of Replacement of Fish Meal by Fermented Soybean Meal on Growth Performance, Body Composition, Serum Biochemical Indices and Liver Tissue Morphology of Juvenile Large Yellow Croaker (Larimichthys crocea). J. Anim. Nutr. 28, 3493-3502. doi: 10.3969/j.issn.1006-267x.2016.11.016

Floreto, E. A. T., Bayer, R. C., and Brown, P. B. (2000). The effects of soybeanbased diets, with and without amino acid supplementation, on growth and biochemical composition of juvenile American lobster, Homarus americanus. Aquaculture 189, 211-235. doi: 10.1016/s0044-8486(00)00363-x

Gyan, W. R., Yang, Q., Tan, B., Jan, S. S., Jiang, L., Chi, S., et al. (2020). Effects of antimicrobial peptides on growth, feed utilization, serum biochemical indices and disease resistance of juvenile shrimp, Litopenaeus vannamei. Aquac. Res. 51, 1222-1231. doi: 10.1111/are.14473 
Harmon, T. S. (2009). Methods for reducing stressors and maintaining water quality associated with live fish transport in tanks: a review of the basics. Rev. Aquac. 1, 58-66. doi: 10.1111/j.1753-5131.2008.01003.x

He, S., Ding, M., Watson Ray, G., Yang, Q., Tan, B., Dong, X., et al. (2021). Effect of Dietary Vitamin D Levels on Growth, Serum Biochemical Parameters, Lipid Metabolism Enzyme Activities, Fatty Acid Synthase and Hepatic Lipase Mrna Expression for Orange-Spotted Grouper (Epinephelus Coioides) in Growth Mid-Stage. Aquac. Nutr. 27, 655-665. doi: 10.1111/anu.13212

Holland, M. C., and Lambris, J. D. (2002). The complement system in teleosts. Fish Shellfish Immunol. 12, 399-420. doi: 10.1006/fsim.2001.0408

Hou, L. (2012). Research progress of soybean peptides and sports medicine. Gansu Med. 31, 907-909. doi: 10.15975/j.cnki.gsyy.2012.12.042

$\mathrm{Hu}$, J. C. (2004). Control of fatty liver disease in factory farmed ovine pomfret. Sci. Fish Farm. 1:42.

Hu, L., Yun, B., Xue, M., Wang, J., Wu, X., Zheng, Y., et al. (2013). Effects of Fish Meal Quality and Fish Meal Substitution by Animal Protein Blend on Growth Performance, Flesh Quality and Liver Histology of Japanese Seabass (Lateolabrax Japonicus). Aquaculture 37, 52-61. doi: 10.1016/j.aquaculture. 2012.10.025

Huang, W. (2015). Research Progress on the Application in Aquaculture of Soybean Peptide Protein Feeds. Taiwan Agric. Exploration 2, 67-70.

Hussain, M. M., Rava, P., Pan, X., Dai, K., Dougan, S. K., Iqbal, J., et al. (2008). Microsomal triglyceride transfer protein in plasma and cellular lipid metabolism. Curr. Opin. Lipidol. 19, 277-284. doi: 10.1097/MOL. 0b013e3282feea 85

Inoue, N., Fujiwara, Y., Kato, M., Funayama, A., Ogawa, N., Tachibana, N., et al. (2015). Soybean beta-conglycinin improves carbohydrate and lipid metabolism in Wistar rats. Biosci. Biotechnol. Biochem. 79, 1528-1534. doi: 10.1080/ 09168451.2015.1034650

Inoue, N., Nagao, K., Sakata, K., Yamano, N., Gunawardena, P. E., Han, S. Y., et al. (2011). Screening of soy protein-derived hypotriglyceridemic di-peptides in vitro and in vivo. Lipids Health Dis. 10:85. doi: 10.1186/1476-511X-10-85

Jiang, K. J. (2013). Effects of small peptides on growth, muscle quality and physiological and biochemical parameters of juvenile Platichthys stellatus. (M.S.). Shanghai: Shanghai Ocean University.

Jiang, Y. B., Yin, Q. Q., and Yang, Y. R. (2010). Effect of soybean peptides on growth performance, intestinal structure and mucosal immunity of broilers. J. Anim. Physiol. Anim. Nutr. 93, 754-760. doi: 10.1111/j.1439-0396.2008.00864.x

Jing, T. S., Zhou, M. R., Li, Z., Li, Y. L., Sun, W. B., Liang, J. T., et al. (2021). Effects of replacing fish meal with soybean small peptide protein on growth performance, digestive enzyme activity and antioxidant function of juvenile Pelteobagrus fulvidraco. Prog. Fish. Sci. 1-9.

Jiang, S., Wu, X., Li, W., Wu, M., Luo, Y., Lu, S., et al. (2015). Effects of Dietary Protein and Lipid Levels on Growth, Feed Utilization, Body and Plasma Biochemical Compositions of Hybrid Grouper (Epinephelus Lanceolatus $\sigma^{\top} \times$ Epinephelus Fuscoguttatus 우) Juveniles. Aquaculture 446, $148-155$.

Kim, K. N., Joo, E. S., Kim, K. I., Kim, S.-K., Yang, H. P., and Jeon, Y.-J. (2005). Effect of Chitosan Oligosaccharides on Cholesterol Level and Antioxidant Enzyme Activities in Hypercholesterolemic Rat. J. Kor. Soc. Food Sci. Nutr. 34, 36-41 doi: 10.3746/jkfn.2005.34.1.036

Kong, X., Guo, M., Hua, Y., Cao, D., and Zhang, C. (2008). Enzymatic Preparation of Immunomodulating Hydrolysates from Soy Proteins. Bioresour. Technol. 99, 8873-8879. doi: 10.1016/j.biortech.2008.04.056

Kotzamanis, Y. P., Gisbert, E., Gatesoupe, F. J., Zambonino Infante, J., and Cahu, C. (2007). Effects of Different Dietary Levels of Fish Protein Hydrolysates on Growth, Digestive Enzymes, Gut Microbiota, and Resistance to Vibrio Anguillarum in European Sea Bass (Dicentrarchus Labrax) Larvae. Comp. Biochem. Physiol. A Mol. Integr. Physiol. 147, 205-214. doi: 10.1016/j.cbpa.2006. 12.037

Kou, H. Y., Xu, S. Y., and Wang, A. L. (2015). Effect of replacing canola meal for fish meal on the growth, digestive enzyme activity, and amino acids, of ovate pompano, Trachinotus ovatus. Isr. J. Aquac. Bamidgeh 67, 1-10. doi: 10.46989/001c.20720

Li, E. C., Chen, L. Q., Gu, S. Z., and Cai, Y. Y. (2009). Evaluation method of nutritional value of aquatic feed protein source. Mar. Sci. 113-117.

Li, M., Xu, C., Ma, Y., Ye, R., Chen, H., Xie, D., et al. (2020). Effects of dietary n-3 highly unsaturated fatty acids levels on growth, lipid metabolism and innate immunity in juvenile golden pompano (Trachinotus ovatus). Fish Shellfish Immunol. 105, 177-185. doi: 10.1016/j.fsi.2020.06.060

Li, M. M., Zhang, M., Ma, Y. C., Ye, R. K., Wang, M., Chen, H. Y., et al. (2020). Dietary supplementation with $\mathrm{n}-3$ high unsaturated fatty acids decreases serum lipid levels and improves flesh quality in the marine teleost golden pompano Trachinotus ovatus. Aquaculture 516:734632. doi: 10.1016/j.aquaculture.2019. 734632

Liang, D., Wang, J., Warson Ray, G., Yang, Q., Tan, B., Dong, X., et al. (2020a). Effects of Different Dietary Levels of Soybean Protein Hydrolysates on the Growth Performance, Antioxidant Capacity and Relative Mrna Expression Levels of Juvenile Hybrid Grouper (Epinephelus Fuscoguttatus $\times$ Epinephelus Lanceolatus $\mathrm{O}^{7}$ ). Aquac. Nutr. 26, 1857-1870. doi: 10.1111/anu.13134

Liang, D., Yang, Q., Tan, B., Dong, X., Chi, S., Liu, H., et al. (2020b). Dietary vitamin A deficiency reduces growth performance, immune function of intestine, and alters tight junction proteins of intestine for juvenile hybrid grouper (Epinephelus fuscoguttatus $\$ \times$ Epinephelus lanceolatus $\sigma^{7}$ ). Fish Shellfish Immunol. 107, 346-356. doi: 10.1016/j.fsi.2020.10.016

Lin, A. Y., Wang, W. Z., Chen, G., Zhang, J. D., Huang, J. S., Pan, C. H., et al. (2020). Effects of Two Lactic Acid Bacteria on Growth Performance and Activities of Digestive and Non-specific Immune Enzymes of Juvenile Cobia (Rachycentroncanadum). J. Guangdong Ocean Univ. 40, 112-117. doi: 10.3969/ j.issn.1673-9159.2020.05.014

Lin, H., Chen, X., Chen, S., Zhuo, J. L., Huang, Z., Niu, J., et al. (2012). Replacement of Fish Meal with Fermented Soybean Meal in Practical Diets for Pompano Trachinotus Ovatus. Aquac. Res. 44, 151-156.

Lin, H., Yang, Q., Wang, A., Wang, J., Tan, B., Ray, G. W., et al. (2021). Effects of Fish Meal under Different Storage Conditions on Growth, Serum Biochemical Indices and Antioxidant Capacity for Juvenile Grouper Epinephelus Coioides. Aquac. Nutr. 27, 723-733. doi: 10.1111/anu.13218

Lin, Q. C., Fang, C. F., Zhong, G. F., Feng, Y., and Zhu, B. Y. (2010). Effect of dietary small peptides on growth and non-specific immunity of Penaeus vannamei larvae. Zhejiang J. Agric. 22, 590-595.

Lin, Y. F., Shao, X. P., Jin, Y., Zhang, Y. X., Wu, C. L., Wang, C. L., et al. (2019). Effects of Fish Meal Replacement by Animal and Plant Protein Mixture on Morphology Indexes, Tissue Fatty Acid Composition, Serum Biochemical Indexes and Hepatic Histology of Juvenile Black Carp (Mylopharyngodon piceus). J. Anim. Nutr. 31, 732-745. doi: 10.3969/j.issn.1006-267x.2019.02.030

Liu, H. Y., Li, L. X., Ayiku, A., Tang, Z., Fan, W., Tan, B. P., et al. (2021). Effects of Dietary Yeast Culture Supplementation on Growth, Intestinal morphology, Immune, and Disease Resistance in Epinephelus fuscoguttatus $q \times$ Epinephelus lanceolatu $\sigma^{7}$. . J. Guangdong Ocean Univ. 41, 1-11.

Liu, K., Liu, H. Y., Chi, S. Y., Dong, X. H., Yang, Q. H., and Tan, B. P. (2018). Effects of different dietary lipid sources on growth performance, body composition and lipid metabolism-related enzymes and genes of juvenile golden pompano, Trachinotus ovatus. Aquac. Res. 49, 717-725. doi: 10.1111/are.13502

Liu, W., Qian, D., Yang, G. L., Zhang, Y. F., and Wang, J. Y. (2004). A Study on the Pathogen of Luminous Bacterial Disease of Penaeus vannamei Post-Larvae During Desalinization. J. Jimei Univ. 4, 300-304. doi: 10.19715/j.jmuzr.2004.04. 003

Liu, Y. B., Wang, F., Tian, C. Y., Dalai, and Rong, W. H. (2007). Utilizing the advantages of animal husbandry resources to accelerate the development of sheep farming in Inner Mongolia. Chin. Herbivore 4, 22-25.

Ma, H., Liu, R., Zhao, Z., Zhang, Z., Cao, Y., Ma, Y., et al. (2016). A Novel Peptide from Soybean Protein Isolate Significantly Enhances Resistance of the Organism under Oxidative Stress. PLoS One 11:e0159938. doi: 10.1371/journal. pone.0159938

Ma, H. Y., Yang, Q. H., Dong, X. H., Tan, B. P., Chi, S. Y., and Liu, H. Y. (2014). Dietary Requirement of Juvenile Grouper. Epinephelus coioides for Hydroxy Methionine Copper. J. Guangdong Ocean Univ. 34, 19-26.

Martínez-Llorens, S., Baeza-Ariño, R., Nogales-Mérida, S., Jover-Cerdá, M., and Tomás-Vidal, A. (2012). Carob seed germ meal as a partial substitute in gilthead sea bream (Sparus aurata) diets: amino acid retention, digestibility, gut and liver histology. Aquaculture 338-341, 124-133. doi: 10.1016/j.aquaculture.2012.01. 029

Monentcham, S. E., Pouomogne, V., and Kestemont, P. (2010). Influence of Dietary Protein Levels on Growth Performance and Body Composition of African Bonytongue Fingerlings, Heterotis Niloticus (Cuvier, 1829). Aquac. Nutr. 16, 144-152. doi: 10.1111/j.1365-2095.2008.00646.x 
Nagasawa, A., Fukui, K., Kojima, M., Kishida, K., Maeda, N., Nagaretani, H., et al. (2003). Divergent effects of soy protein diet on the expression of adipocytokines. Biochem. Biophys. Res. Commun. 311, 909-914. doi: 10.1016/j.bbrc.2003.1 0.087

Nagayoshi, A., Matsuki, N., Saito, H., Tsukamoto, K., Kaneko, K., Wakashima, M., et al. (1995). Defect in Assembly Process of Very-Low-Density Lipoprotein in Suncus Liver: an Animal Model of Fatty Liver. J. Biochem. 117, 787-93. doi: 10.1093/oxfordjournals.jbchem.a124777

Naylor, R. L., Goldburg, R. J., Primavera, J. H., Kautsky, N., Beveridge, M. C., Clay, J., et al. (2000). Effect of Aquaculture on World Fish Supplies. Nature 405, 1017-1024. doi: 10.1038/35016500

Nilsson-Ehle, P., Garfinkel, A. S., and Schotz, M. C. (1980). Lipolytic enzymes and plasma lipoprotein metabolism. Annu. Rev. Biochem. 49, 667-693. doi: 10.1146/annurev.bi.49.070180.003315

Niu, J., Figueiredo-Silva, C., Dong, Y., Yue, Y. R., Lin, H. Z., Wang, J., et al. (2016). Effect of Replacing Fish Meal with Soybean Meal and of Dl-Methionine or Lysine Supplementation in Pelleted Diets on Growth and Nutrient Utilization of Juvenile Golden Pompano (Trachinotus Ovatus). Aquac. Nutr. 22, 606-614. doi: 10.1111/anu.12284

Pearce, G., Munske, G., Yamaguchi, Y., and Ryan, C. A. (2010). Structure-activity studies of GmSubPep, a soybean peptide defense signal derived from an extracellular protease. Peptides 31, 2159-2164. doi: 10.1016/j.peptides.2010.09. 004

Puchalska, P., García, M. C., and Marina, M. L. (2014). Development of a Capillary High Performance Liquid Chromatography-Ion Trap-Mass Spectrometry Method for the Determination of Vlivp Antihypertensive Peptide in Soybean Crops. J. Chromatogr. A 1338, 85-91. doi: 10.1016/j.chroma.2014.02.059

Qu, Y. J., Fan, C. Y., Li, J. E., and Yu, N. (2014). Effects of salinity on the osmoregulation and weight loss from starvation in Trachinotus ovatus juvenile. J. Ecol. 24, 293-300. doi: 10.5846/stxb201303190450

Savoie, A., Le François, N. R., Cahu, C., Blier, P. U., and Andreassen, I. (2006). Do Protein Hydrolysates Improve Survival and Growth of Newly-Hatched Spotted Wolffish (Anarhichas Minor), a Non-Metamorphic Aquaculture Fish Species?. Aquaculture 261, 782-788. doi: 10.1016/j.aquaculture.2006.08.047

Shen, J. F., Chen, M. C., Liu, H. Y., Tan, B. P., Dong, X. H., Yang, Q. H., et al. (2019). Effects of Fish Meal Replacement by Concentrated Cottonseed Protein on Growth Performance, Serum Biochemical Indices, Liver Antioxidant Indices and Gastrointestinal Tract Protease Activities of Juvenile Trachinotus ovatus. J. Anim. Nutr. 31, 746-756.

Shi, X., Luo, Z., Huang, C., Zhu, X. M., and Liu, X. (2015). Effects of substituting chlorella sp. For regular fish meal on growth, body composition, hepatic lipid metabolism and histology in crucian carp Carassius curatus. J. Aquat. Biol. 39, 498-506.

Tacon, A. G. J., and Metian, M. (2008). Global overview on the use of fish meal and fish oil in industrially compounded aquafeeds: trends and future prospects. Aquaculture 285, 146-158. doi: 10.1016/j.aquaculture.2008.08.015

Tacon, A. J. (2003). Aquaculture Production Trends Analysis. Prog. Theor. Phys. 46, 1-14. doi: 10.1143/PTP.46.1

Tan, X., Sun, Z., Huang, Z., Zhou, C., Lin, H., Tan, L., et al. (2017). Effects of dietary hawthorn extract on growth performance, immune responses, growthand immune-related genes expression of juvenile golden pompano (Trachinotus ovatus) and its susceptibility to Vibrio harveyi infection. Fish Shellfish Immunol. 70, 656-664. doi: 10.1016/j.fsi.2017.09.041

Tan, X., Sun, Z., Zhou, C., Huang, Z., Tan, L., Xun, P., et al. (2018). Effects of dietary dandelion extract on intestinal morphology, antioxidant status, immune function and physical barrier function of juvenile golden pompano Trachinotus ovatus. Fish Shellfish Immunol. 73, 197-206. doi: 10.1016/j.fsi.2017.12.020

Tseng, D. Y., Ho, P. L., Huang, S. Y., Cheng, S. C., Shiu, Y. L., Chiu, C. S., et al. (2009). Enhancement of immunity and disease resistance in the white shrimp, Litopenaeus vannamei, by the probiotic, Bacillus subtilis E20. Fish Shellfish Immunol. 26, 339-344. doi: 10.1016/j.fsi.2008.12.003

Tutman, P., Glavić, N., Kožul, V., Skaramuca, B., and Glamuzina, B. (2004). Preliminary Information on Feeding and Growth of Pompano, Trachinotus Ovatus (Linnaeus, 1758) (Pisces; Carangidae) in Captivity. Aquac. Int. 12, 387-393. doi: 10.1023/B:AQUI.0000042135.88381.f4

Wang, A. J., Yang, Q. H., Tan, B. P., Xiao, W. W., Jia, J., Dong, X. H., et al. (2018). Effects of Enzymolytic Soybean Meal on Growth Performance, Serum Biochemical Indices, Non-specific Immunity and Disease Resistance of Juvenile
Litopenaeus vannamei. J. Guangdong Ocean Univ. 38, 14-21. doi: 10.3969/j.issn. 1673-9159.2018.01.003

Wang, J. X., Liang, D. Z., Yang, Q. H., Tan, B. P., Dong, X. H., Chi, S. Y., et al. (2020). The effect of partial replacement of fish meal by soy protein concentrate on growth performance, immune responses, gut morphology and intestinal inflammation for juvenile hybrid grouper (Epinephelus fuscoguttatuso $\times$ Epinephelus lanceolatuso' ${ }^{7}$ ). Fish Shellfish Immunol. 98, 619-631. doi: 10.1016/ j.fsi.2019.10.025

Wang, J., Zhang, H., Yang, Q., Tan, B., Dong, X., Chi, S., et al. (2020). Effects of replacing soybean meal with cottonseed meal on growth, feed utilization and non-specific immune enzyme activities for juvenile white shrimp, Litopenaeus vannamei. Aquac. Rep. 16:100255. doi: 10.1016/j.aqrep.2019.10 0255

Wang, S. J., Zhang, H. F., Zhao, J., Yang, Y. Q., and Yang, S. S. (2011). Effects of Different Salinities on the Growth and Physiology of Orange-Spotted Grouper, Epinephelus coioides. J. Guangdong Ocean Univ. 31, 39-44.

Wang, T., Fu, Y. M., Lu, J. L., Jiang, H. S., Li, Y. P., Chen, C. Y., et al. (2003). Effect of mini-peptide on the growth performance and the development of small intestines in weaning piglets. Livestock Vet. Med. 35, 4-8.

Wang, X. F., Li, X. Q., Leng, X. J., Shan, L. L., Zhao, J. X., and Wang, Y. T. (2014). Effects of Dietary Cottonseed Meal Level on the Growth, Hematological Indices, Liver and Gonad Histology of Juvenile Common Carp (Cyprinus Carpio). Aquaculture 428-429, 79-87. doi: 10.1016/j.aquaculture.2014.02.040

Wang, Y. R., Wang, L., Zhang, C. X., and Song, K. (2017). Effects of Substituting Fish meal with Soybean Meal on Growth Performance and Intestinal Morphology in Orange-Spotted Grouper (Epinephelus coioides). Aquac. Rep. 5, 52-57. doi: 10.1016/j.aqrep.2016.12.005

Wang, C. A., Xu, Q., Xu, H., Chang, Y., Zhu, Q., and Sun, D. (2010). Effects of replacing fish meal with small peptides on growth performance, body composition and serum indices of Acipenser baerii Brandt. J. Chin. Cereals Oils Assoc. 25, 55-58+64.

Weng, X. J., Wu, X. F., Tian, J., Li, X. Q., Guan, L., and Weng, D. C. (2012). Molecular cloning of fatty acid synthase from grass carp (Ctenopharyngodon idella) and the regulation of its expression by dietary fat level. Aquac. Nutr. 18, 551-558. doi: 10.1111/j.1365-2095.2011.00917.x

Wu, L. F., Qin, G. X., Sun, Z. W., Wang, H. H., Zhang, D. M., Sun, L., et al. (2010). Effect of Dietary Dehulled Soyabean Meal Replacing Fish Meal on the Activity of Digestive Enzyme and the Intestinal Tissue of Clarias lazera. J. Zhongshan Univ. 49, 99-105.

Wu, L. F., Xing, X. P., Lai, H. E., Yang, H. H., Qin, G. X., and Yang, H. (2014). Effects of soybean antigen protein Glycinin on intestinal tissues of larval and juvenile Common carps. J. Northwest Agric. For. Univ. Sci. Technol. 42, 7-14. doi: 10.13207/j.cnki.jnwafu.2014.10.065

Wu, Y. C., Li, R. M., Shin, G. R., Huang, F., Yang, Q. H., Tan, B. P., et al. (2021). Effects of dietary small peptides on growth, antioxidant capacity, nonspecific immunity and ingut microflora structure of Litopenaeus vannamei. J. Guangdong Ocean Univ. 41, 1-9. doi: 10.3969/j.issn.1673-9159.2021.05.001

Xie, J., Fang, H., He, X., Liao, S., Liu, Y., Tian, L., et al. (2020). Study on mechanism of synthetic astaxanthin and Haematococcus pluvialis improving the growth performance and antioxidant capacity under acute hypoxia stress of golden pompano (Trachinotus ovatus) and enhancing anti-inflammatory by activating Nrf2-ARE pathway to antagonize the NF-кB pathway. Aquaculture 518:734657. doi: 10.1016/j.aquaculture.2019.734657

Xie, J., Fang, H., Liao, S., Guo, T., Yin, P., Liu, Y., et al. (2019). Study on Schizochytrium sp. improving the growth performance and non-specific immunity of golden pompano (Trachinotus ovatus) while not affecting the antioxidant capacity. Fish Shellfish Immunol. 95, 617-623. doi: 10.1016/j.fsi. 2019.10.028

Xie, J. H., Qiu, D. Q., Liu, C. X., Zhu, W. W., and Zeng, L. (2013). Effcets of Vibrio alginolyticus Peptidoglycan on Astaxanthin Level, Immune Indicators and Protection in Litopenaeus vannamei. J. Guangdong Ocean Univ. 33, 50-55.

Yan, J., Liao, K., Wang, T., Mai, K., Xu, W., and Ai, Q. (2015). Dietary Lipid Levels Influence Lipid Deposition in the Liver of Large Yellow Croaker (Larimichthys crocea) by Regulating Lipoprotein Receptors, Fatty Acid Uptake and Triacylglycerol Synthesis and Catabolism at the Transcriptional Level. PLoS One 10:e0129937. doi: 10.1371/journal.pone.0129937

Yang, Q., Ding, M., Tan, B., Dong, X., Chi, S., Zhang, S., et al. (2017). Effects of dietary vitamin A on growth, feed utilization, lipid metabolism enzyme 
activities, and fatty acid synthase and hepatic lipase mRNA expression levels in the liver of juvenile orange spotted grouper, Epinephelus coioides. Aquaculture 479, 501-507. doi: 10.1016/j.aquaculture.2017.06.024

Yildirim, O., Ergun, S., Yaman, S., and Turker, A. (2009). Effects of Two Seaweeds (Ulva lactuca and Enteromorpha linza) as a Feed Additive in Diets on Growth Performance, Feed Utilization, and Body Composition of Rainbow Trout (Oncorhynchus mykiss). Kafkas Universitesi Veteriner Fakultesi Dergisi 15, 455460.

Zarkadis, I. K., Mastellos, D., and Lambris, J. D. (2001). Phylogenetic aspects of the complement system. Dev. Comp. Immunol. 25, 745-762. doi: 10.1016/s0145305x(01)00034-9

Zhang, C. X., Rahimnejad, S., Wang, Y. R., Lu, K. L., Song, K., Wang, L., et al. (2018). Substituting Fish Meal with Soybean Meal in Diets for Japanese Seabass (Lateolabrax Japonicus): effects on Growth, Digestive Enzymes Activity, Gut Histology, and Expression of Gut Inflammatory and Transporter Genes. Aquaculture 483, 173-182. doi: 10.1016/j.aquaculture.2017.10.029

Zhang, J., Li, W., Ying, Z., Zhao, D., Yi, G., Li, H., et al. (2020). Soybean proteinderived peptide nutriment increases negative nitrogen balance in burn injuryinduced inflammatory stress response in aged rats through the modulation of white blood cells and immune factors. Food Nutr. Res. 64:3677. doi: 10.29219/ fnr.v64.3677

Zhang, K., Liu, S. C., Fan, X. P., Wei, S., Sun, Q. X., Xia, Q. Y., et al. (2021). Review on Strategies and Key Technologies of Live Fish Transportation. J. Guangdong Ocean Univ. 41, 137-144. doi: 10.3969/j.issn.1673-9159.2021.05.018

Zhang, M., Chen, C., You, C., Chen, B., Wang, S., and Li, Y. (2019). Effects of different dietary ratios of docosahexaenoic to eicosapentaenoic acid (DHA/EPA) on the growth, non-specific immune indices, tissue fatty acid compositions and expression of genes related to LC-PUFA biosynthesis in juvenile golden pompano Trachinotus ovatus. Aquaculture 505, 488-495. doi: 10.1016/j.aquaculture.2019.01.061

Zhang, Y. C., Li, D. F., Fan, S. J., Piao, X. S., Wang, J. T., and Han, I. K. (2002). Effects of casein and protein-free diets on endogenous amino acid losses in pigs. Asian Austral. J. Anim. 15, 1634-1638. doi: 10.5713/ajas.2002.1634

Zhang, Y. J., Shi, L., Xie, T., and Zhong, G. F. (2020). Effects of Soybean Peptide Replacement with Fish Meal on Intestinal Microflora Structure of Pacific White Shrimp, Litopenaeus vannamei. Genomics Appl. Biol. 39, 5084-5090. doi: 10. 13417/j.gab.039.005084

Zhao, S. Y., Lin, H. Z., Huang, Z., Zhou, C. P., Wang, J., Wang, Y., et al. (2016). Effect of small peptide supplementation at different protein levels growth performance, digestive enzymes activities, serum biochemical indices and antioxidant abilities of grouper (Epinephelus akaara). Southern Fish. Sci. $12,15-23$.

Zhao, Z. X., Song, C. Y., Xie, J., Ge, X. P., Liu, B., Xia, S. L., et al. (2016). Effects of Fish Meal Replacement by Soybean Peptide on Growth Performance, Digestive Enzyme Activities, and Immune Responses of Yellow Catfish Pelteobagrus Fulvidraco. Fish. Sci. 82, 665-673. doi: 10.1007/s12562-016-0996-6

Zheng, Q., Wen, X., Han, C., Li, H., and Xie, X. (2012). Effect of Replacing Soybean Meal with Cottonseed Meal on Growth, Hematology, Antioxidant Enzymes
Activity and Expression for Juvenile Grass Carp, Ctenopharyngodon Idellus. Fish. Physiol. Biochem. 38, 1059-1069. doi: 10.1007/s10695-011-9590-0

Zheng, Y. F., Xu, Y. Y., and Xu, Y. J. (2006). New advances in the study of small peptides for protein nutrition. Feed Industry 27, 16-18.

Zhou, C., Lin, H., Huang, Z., Wang, J., Wang, Y., and Yu, W. (2020). Effects of dietary leucine levels on intestinal antioxidant status and immune response for juvenile golden pompano (Trachinotus ovatus) involved in Nrf2 and NFkappaB signaling pathway. Fish Shellfish Immunol. 107, 336-345. doi: 10.1016/ j.fsi.2020.10.012

Zhou, W., Rahimnejad, S., Lu, K., Wang, L., and Liu, W. (2019). Effects of berberine on growth, liver histology, and expression of lipid-related genes in blunt snout bream (Megalobrama amblycephala) fed high-fat diets. Fish Physiol. Biochem. 45, 83-91. doi: 10.1007/s10695-018-0536-7

Zhou, X. G., Tang, G. H., Deng, F. C., Shen, J. M., Liang, Y., Liu, K., et al. (2011). Effect of small peptide replacing plasma protein powder on production performance of weaned piglets. Foreign Anim. Husbandry 30, 64-65.

Zhou, X. Q. (2012). Relationship between nutrients and intestinal health of fish. Chinese Society of Animal Husbandry and Veterinary Medicine, Animal Nutrition Branch. Adv. Anim. Nutr. Res. 253-267.

Zhu, Q. G., Lin, J. B., Huang, C. J., Chen, D. H., Liang, P., Qin, C. Q., et al. (2012). Effects of Dietary n-3 Highly Unsaturated Fatty Acids on Growth and Muscle Fatty Acid Composition of Juvenile Grouper (Epinephlus coioides). J. Guangdong Ocean Univ. 32, 20-27.

Zhu, Z., Yang, Q., Tan, B., Zhou, X., Dong, X., Chi, S., et al. (2021). Effects of replacing fish meal with soybean protein concentrate (SPC) on growth, blood biochemical indexes, non-specific immune enzyme activity, and nutrient apparent digestibility for juvenile Litopenaeus vannamei. Aquac. Int. 29, 25352554. doi: 10.1007/s10499-021-00765-8

Conflict of Interest: MZ and ML were employed by the company Yisheng (Yangjiang) Biotechnology Company Limited.

The remaining authors declare that the research was conducted in the absence of any commercial or financial relationships that could be construed as a potential conflict of interest.

Publisher's Note: All claims expressed in this article are solely those of the authors and do not necessarily represent those of their affiliated organizations, or those of the publisher, the editors and the reviewers. Any product that may be evaluated in this article, or claim that may be made by its manufacturer, is not guaranteed or endorsed by the publisher.

Copyright $\odot 2022$ Lin, Tan, Ray, Zeng, Li, Chi and Yang. This is an open-access article distributed under the terms of the Creative Commons Attribution License (CC BY). The use, distribution or reproduction in other forums is permitted, provided the original author(s) and the copyright owner(s) are credited and that the original publication in this journal is cited, in accordance with accepted academic practice. No use, distribution or reproduction is permitted which does not comply with these terms. 